Dissertationes Forestales 196

\title{
Ecological interactions between herbivores and silver birch and aspen trees genetically modified for fungal disease resistance
}

\author{
Liisa Vihervuori \\ Department of Forest Sciences \\ Faculty of Agriculture and Forestry \\ University of Helsinki
}

\begin{abstract}
Academic dissertation
To be presented, with the permission of the Faculty of Agriculture and Forestry of the University of Helsinki, for public criticism in the auditorium B4 at Viikki (Latokartanonkaari 7, Helsinki) on June 26th, at 12 o'clock.
\end{abstract}


Title of the dissertation: Ecological interactions between herbivores and silver birch and aspen trees genetically modified for fungal disease resistance

Author: Liisa Vihervuori

Dissertationes Forestales 196

http://dx.doi.org/10.14214/df.196

Thesis Supervisors:

Associate Professor Päivi Lyytikäinen-Saarenmaa

Department of Forest Sciences, University of Helsinki, Finland

PhD Hanna-Leena Pasonen

Department of Forest Sciences, University of Helsinki.

Current position: Environmental manager, City of Mikkeli, Finland

Pre-examiners:

Professor Joakim Hjältén

Department of Wildlife, Fish and Environmental Studies, Swedish University of Agricultural Sciences, Sweden

Prof. Riitta Julkunen-Tiitto

Department of Biology, University of Eastern Finland, Finland

Opponent:

Professor Jarmo Holopainen

Department of Environmental Science, University of Eastern Finland, Finland

ISSN 1795-7389 (online)

ISBN 978-951-651-481-2 (pdf)

ISSN 2323-9220 (print)

ISBN 978-951-651-482-9 (paperback)

2015

Publishers:

Finnish Society of Forest Science

Natural Resources Institute Finland

Faculty of Agriculture and Forestry at the University of Helsinki

School of Forest Sciences at the University of Eastern Finland

Editorial Office:

Finnish Society of Forest Science

P.O. Box 18, FI-01301 Vantaa, Finland

http://www.metla.fi/dissertationes 
Vihervuori, L. 2015. Ecological interactions between herbivores and silver birch and aspen trees genetically modified for fungal disease resistance. Dissertationes Forestales 196. 52 p. Available at http://dx.doi.org/10.14214/df.196

\begin{abstract}
Many risks and environmental concerns have been linked with the cultivation of genetically modified (GM) trees. Among the most frequently mentioned risks are the unintentional/pleiotropic effects of transgenes on organisms or plant properties that are not the targets of genetic modification. Risks in forest ecosystems are difficult to predict, due to the long life cycles of trees and their complex ecological interactions. This thesis is focused on the interactions between insect and mammal herbivores and transgenic trees. The studied silver birch (Betula pendula Roth) carried a sugar beet chitinase IV gene and the aspen and hybrid aspen (Populus sp.) carried a pine pinosylvin synthase gene, both aiming to improve the trees' resistance to fungal diseases, but also potentially affecting insect and mammal herbivores.
\end{abstract}

Tree growth and quality, and insect density and composition were studied during the field trial. The palatability of transgenic trees was studied in the feeding experiments using the lepidopteran herbivores rusty tussock moth and buff-tip (Orgyia antiqua L., Phalera bucephala L.) and the mammalian herbivores mountain hare and roe deer (Lepus timidus L., Capreolus capreolus L.).

The studies revealed that sugar beet chitinase IV caused unintentional effects on silver birch: the transgenic trees were smaller and their red leaf colour indicated stress. There were differences in herbivore pressure between transgenic and wild-type birches: GM trees had a higher aphid density but a lower diversity of insect species and visible leaf damages. The relative growth rate of $O$. antiqua on transgenic birches was lower in comparison to wild-type birches. No difference in the palatability to mammals was found between transgenic and wild-type trees. The results suggest that the impact on herbivores is speciesdependent. The pleiotropic effects of the transgenes affecting plant-herbivore interaction can explain these impacts. These results should be taken into account when considering the biosafety of GM trees.

Keywords: transgenic tree, cafeteria trial, field trial, herbivory, non-target effect, chitinase, pinosylvin synthase 
Vihervuori, L. 2015. Ekologiska interaktioner mellan herbivorer och träd (björkar och aspar) som är genetiskt modifierade för resistens mot svampsjukdomar. Dissertationes Forestales 196. 52 p. http://dx.doi.org/10.14214/df.196

\section{SAMMANFATTNING}

Transgena träd (GMO-träd) kan medföra risker och miljöproblem. En av de främsta riskerna är oförutsedda/pleiotropiska effekter på andra organismer. Särskilt i skogsekosystem är riskerna svåra att förutse på grund av trädens långa livstid och komplexa ekologiska interaktioner med andra organismer. Denna avhandling undersöker interaktioner mellan herbivorer (insekter och däggdjur) och transgena träd, dvs. vårtbjörk (Betula pendula Roth), asp och hybridasp (Populus sp.). Björkarna som ingick i undersökningen var försedda med en gen (från sockerbeta) som producerar kitinas IV, och asparna med en gen (från tall) som producerar pinosylvinsyntas, bägge i syfte att motverka svampsjukdomar. Transgenerna påverkar eventuellt också herbivorerna.

I ett fältexperiment undersöktes trädens tillväxt och kvalitativa egenskaper samt tätheten av vanligt förekommande växtätande insekter på träden. Matningsexperiment med fjärilar av arterna aprikostofsspinnare och oxhuvudspinnare (Orgyia antiqua L., Phalera bucephala L.) samt skogsharar och rådjur (Lepus timidus L., Capreolus capreolus L.) syftade till att undersöka om genmodifieringen påverkade trädens smaklighet för dessa växtätare.

Resultaten visade oförutsedda verkningar hos de kitinastransgena björkarna. Deras tillväxt var sämre än kontrollträdens och bladen färgades röda, vilket är en indikation på stress. De transgena trädens utsatthet för herbivorer skilde sig från kontrollträden: sammansättningen av herbivora arter och skadorna på bladen hos de transgena träden var mindre varierande, men antalet bladlöss var större än hos kontrollträden. Den relativa tillväxten av $O$. antiqua på transgena björkar var lägre i jämförelse med björkar av vildtyp. I matningsexperimenten med däggdjur förekom ingen skillnad i smaklighet mellan de transgena träden och kontrollträden. Resultaten ger även stöd för antagandet att de genetiska modifikationerna påverkar olika herbivorer på olika sätt. Resultaten kan förklaras av transgenernas pleiotropiska effekter som påverkar interaktionen mellan växterna och herbivorerna. Resultaten bör beaktas vid framtida riskbedömningar av transgena träd.

Nyckelord: GMO-träd, matningsexperiment, fältexperiment, oförutsedd verkning, kitinas, pinosylvinsyntas 
Vihervuori, L. 2015. Ökologische Interaktionen zwischen Pflanzenfressern und Bäume (Weißbirken und Espen), die bezüglich ihrer Resistenz gegen Pilzkrankheiten gentechnisch verändert wurden. Dissertationes Forestales 196. 52 p. http://dx.doi.org/10.14214/df.196

\section{ZUSAMMENFASSUNG}

Mit dem Anbau von gentechnisch veränderten Bäumen (GV-Bäumen) sind viele verschiedene Risiken und ökologische Belange in Verbindung gebracht worden. Eines der am häufigsten genannten Risiken ist mit den unbeabsichtigten Wirkungen (den pleitropen Effekten) der Transgene auf Organismen oder solche Eigenschaften der Pflanzen verbunden, die nicht Ziele der gentechnischen Veränderung sind. Besonders in Waldökosystemen sind die Wirkungen wegen der langen Lebenszyklen und der komplexen ökologischen Wechselwirkungen schwer vorhersehbar. In dieser Untersuchung wurden die Interaktionen zwischen transgenen Bäumen $-\mathrm{d}$. h. Weißbirke (Betula pendula Roth) und Espe (Populus sp.) - einerseits und Pflanzenfressern andererseits untersucht. Die Birken waren mit einem Gen von der Zuckerrübe versehen, welches das Enzym Chitinase IV produziert, und die Espen waren mit einem Gen von der Kiefer ausgestattet, welches Pinosylvinsynthase produziert. Die Bäume waren schon im Voraus mit den Transgenen versehen worden, um ihre Resistenz gegen Pilze zu untersuchen. Die Transgene wirken sich möglicherweise aber auch auf pflanzenfressende Insekten und Säugetiere aus.

Im Feldversuch wurde untersucht, ob sich das Wachstum der Bäume und ihre qualitativen Eigenschaften sowie ihr Insektenbefall von denen der Kontrollbäume unterschieden. Bei Fütterungsexperimenten wurde die Tauglichkeit der transgenen Bäume als Nahrung für die Raupen des Schlehen-Bürstenspinners (Orgyia antiqua L.) und des Mondvogels (Phalera bucephala L.) sowie bezüglich der Säugetiere als Nahrung für den Schneehasen (Lepus timidus L.) und das Reh (Capreolus capreolus L.) untersucht.

Das Chitinase-IV-Transgen der Zuckerrübe verursachte unbeabsichtigte Wirkungen auf die Birken: Ihr Wachstum war schwächer, und die rote Färbung der Blätter indizierte Stress. Auch bezüglich des Drucks von Pflanzenfressern gab es Unterschiede zwischen den transgenen Birken und den Wildtyp-Birken: Es traten mehr Blattläuse auf, aber die Artenvielfalt der Schädlinge war geringer und es traten weniger Blattschäden auf. In den Experimenten mit den Insekten war die relative Wachstumsrate der Raupen von O. antiqua bei den transgenen Blättern schwächer als bei den Blättern der Kontrollbäume. In den Experimenten mit der Verfütterung der Blätter an Säugetiere wurde kein Unterschied in der Tauglichkeit zwischen den transgenen Bäumen und den Kontrollbäumen festgestellt. Die Ergebnisse legen nahe, dass die Wirkung auf Pflanzenfresser von der jeweiligen Art abhängt, was sich durch die pleiotropen Effekte der transgenen Pflanzen erklären lässt, welche die Pflanzenfresser-Interaktion beeinflussen. Diese Ergebnisse sollten berücksichtigt werden, wenn die biologische Sicherheit gentechnisch veränderter Bäume erwogen wird.

Schlüsselwörter: GV-Baum, Fütterungsexperiment, Feldstudie, unbeabsichtigte Wirkung, Chitinase, Pinosylvinsynthase 


\section{ACKNOWLEDGEMENTS}

My work with transgenic trees began in 2003 when Dr. Päivi Lyytikäinen-Saarenmaa inspired me to study herbivory within the ongoing field trial at the Viikki campus area of the University of Helsinki. After harvesting of the field trial, I continued working with greenhouse plant material, first in the Department of Applied Biology and then in the Department of Forest Ecology, later the Department of Forest Sciences.

I owe a great deal to my two supervisors and their expert skills: Assoc. Prof. and Dr. Päivi Lyytikäinen-Saarenmaa, Dr. Hanna-Leena Pasonen. They have kept pushing me forward since the very beginning of my studies.

My personal history with forest entomology started when I began drawing pictures of trees and insects at the age of three. My family's history within the Faculty of Agriculture and Forestry dates back to the early 1950's when my grandfather was among the students of the famous grand old man of Finnish forest entomology, Professor Uunio Saalas. As long as I can remember, my father and grandfather have taught me a great deal about the animals and plants that were found around our family's summer place. It was very natural for me as a forestry student to focus on insects.

In am grateful to all those who have financially supported this thesis and given me opportunities to attend important international conferences: the Chancellor of the University of Helsinki, The Finnish Cultural Foundation, the Niemi foundation, the University of Helsinki funds, The Finnish Society of Forest Science, Suomen Hyönteistieteellinen Seura, Suomen Konkordialiitto, and Metsämiesten Säätiö.

I want to cordially thank all my co-authors. Likewise, I would like to thank those who have helped me during the years in different ways: Professor Johanna Mappes (University of Jyväskylä), Professor emeritus Jorma Tahvanainen and Professor Riitta Julkunen-Tiitto (University of Eastern Finland), the staff of the Mekrijärvi Research Station and Former Director thereof, currently Research Director, Professor at the Natural Resources Institute Finland Taneli Kolström, Ähtäri Zoo, Viikki greenhouse, Professor emeritus Juhani Päivänen and Professor emeritus Kim von Weissenberg. A special thanks to the people who shared the office with me: Sari Holopainen, Milla Niemi, Elina Peuhu and Sanna Välimäki.

The pre-reviewers of this thesis, Professor Joakim Hjältén and Professor Riitta Julkunen-Tiitto, are gratefully acknowledged for their constructive comments.

Helsinki, June 2015

Liisa Vihervuori
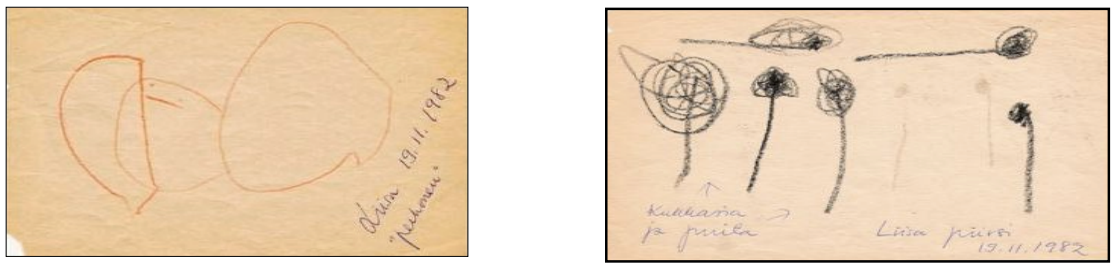

Butterfly (left) and Trees and flowers (right) by 3-year-old L.V. 


\section{LIST OF ORIGINAL ARTICLES}

This thesis consists of an introductory review followed by four research papers. The papers in the review are referred to by their Roman numerals. The articles are reprinted here with the kind permission of the publishers.

I Pasonen H.-L., Vihervuori L., Seppänen S.-K., Lyytikäinen-Saarenmaa P., Ylioja T., von Weissenberg K., Pappinen A. (2008). Field performance of chitinase transgenic silver birch (Betula pendula Roth): growth and adaptive traits. Trees - Structure and Function 22: 413-421.

http://dx.doi.org/10.1007/s00468-007-0202-7

II Vihervuori L., Pasonen H.-L., Lyytikäinen-Saarenmaa P. (2008). Density and composition of an insect population in a field trial of chitinase transgenic and wild-type silver birch (Betula pendula) clones. Environmental Entomology 37: 1582-1591.

http://dx.doi.org/10.1603/0046-225X-37.6.1582

III Vihervuori L., Lyytikäinen-Saarenmaa P., Lu J., Pasonen H.-L. (2013). Effects of sugar beet chitinase IV on lepidopteran herbivores feeding on transgenic birch (Betula pendula). European Journal of Entomology 110: 253-262. http://dx.doi.org/10.14411/eje.2013.038

IV Vihervuori L., Lyytikäinen-Saarenmaa P., Tuomikoski E., Luoma M., Niemelä P., Pappinen A., Pasonen H.-L. (2012). Palatability of transgenic birch and aspen to roe deer and mountain hare. Biocontrol Science and Technology 22: 11671180 .

http://dx.doi.org/10.1080/09583157.2012.716393

\section{AUTHOR'S CONTRIBUTIONS}

Liisa Vihervuori was responsible for the thesis and studies as follows: author of the thesis summary, main author of papers II, III and IV. Hanna-Leena Pasonen and Päivi Lyytikäinen-Saarenmaa participated in writing articles II, III and IV. In Paper I, Liisa Vihervuori participated in data collection, data analysis and writing. She collected and analyzed the data and drafted the manuscripts for papers II and III, while the molecular and enzyme analyses were performed together with Hanna-Leena Pasonen and Jinrong Lu. Liisa Vihervuori collected and analyzed data and drafted the manuscript of paper IV together with Hanna-Leena Pasonen and Päivi Lyytikäinen-Saarenmaa, while the other coauthors participated in planning the research and in conducting the feeding trials. 


\section{TABLE OF CONTENTS}

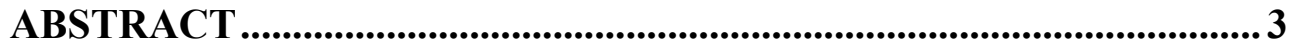

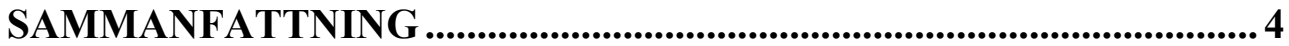

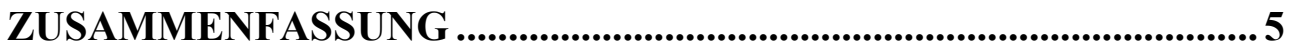

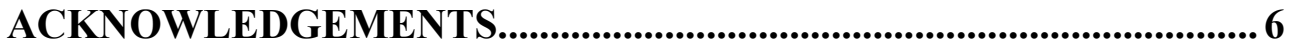

LIST OF ORIGINAL ARTICLES ...................................................... 7

AUTHOR'S CONTRIBUTIONS .......................................................

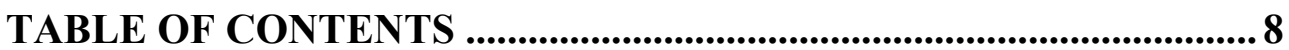

TERMINOLOGY AND ABBREVIATIONS USED ..............................9

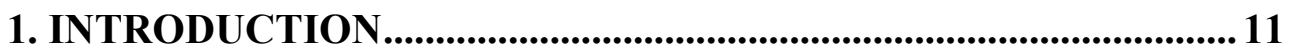

1.1. Genetically modified forest trees ........................................................................... 11

1.2. Non-target and pleiotropic effects of transgenic trees.......................................... 13

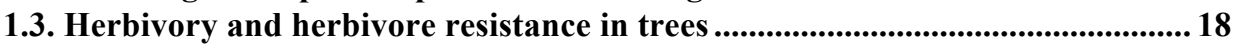

1.4. The potential effects of chitinase and pinosylvin on herbivores......................... 19

1.5. Feeding trials on transgenic trees........................................................................ 21

2. AIMS OF THE STUDY ......................................................................... 22

3. MATERIAL AND METHODS........................................................2 23

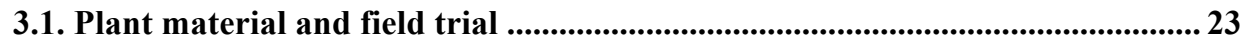

3.2. Molecular and biochemical studies ............................................................. 24

3.3. Tree growth and quality ................................................................................................... 25

3.4. Insect density and composition ...................................................................................... 25

3.5. Feeding trials with insects and mammals ....................................................26

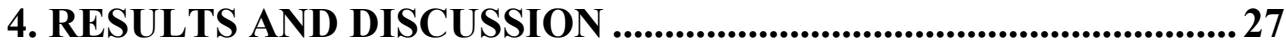

4.1. The impact of transgenes on tree growth and quality ........................................... 27

4.2. The impact of transgenes on herbivory in the field and feeding trials .............. 30

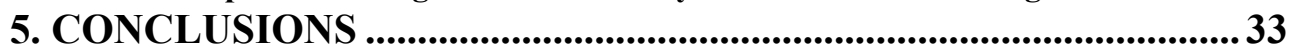

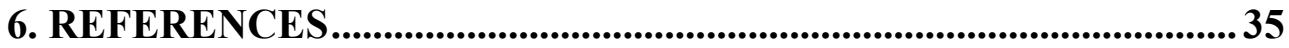




\section{TERMINOLOGY AND ABBREVIATIONS USED}

Adverse: In environmental risk assessment, refers to harmful and undesired reactions, including interactions with other organisms. See 2001/18/EC, Annex II.

Chitinase: Enzymes capable of catalysing the hydrolysis of chitin, a homopolymer of L$1,4-\mathrm{N}$-acetyl-D-glucosamine and a primary structural component of the cell wall of true fungi and arthropod exoskeletons.

Epigenetic: Relating to, being, or involving a modification in gene expression that is independent of a gene's DNA sequence.

Gene expression: The process by which information from a gene is used in the synthesis of a functional gene product, often proteins. The gene expression level is the level at which a particular gene is expressed within a cell, tissue or organism.

GM(O): Genetically modified organism whose genetic material has been altered using genetic engineering techniques. These techniques use DNA molecules from different sources, which are combined into one molecule to create a new set of genes. This DNA is then transferred into an organism, giving it modified or novel genes.

Herbivore: An invertebrate or vertebrate animal that is adapted to consuming plants.

Herbivory: A form of predation in which an organism principally consumes autotrophs such as plants.

Insect (herbivore) guild/Feeding guild: A functional group of insect herbivores that is based on the way in which planta are consumed, e.g. leaf suckers or chewers.

Non-target effect: Any effect of a studied transgene or transgenic organism on other than the targeted species (herbivores, parasitoids, predators, symbionts or other organisms), on ecosystem processes, on effects associated with gene flow or evolutionary effects (see 2001/18/EC, Annex II).

Palatability: Acceptable to the taste: sufficiently agreeable in flavour to be eaten as foods that satisfy nutritional needs. Palatability varies between/within herbivore species and can be learnt.

Performance: The extent to which a herbivore is able to realize maximum growth and reproduction is usually expressed as the rate parameter as RGR (relative growth rate) or other nutritional indices.

Pinosylvin: Stilbenoid toxin that is synthesized prior to infection. It is present in the heartwood of Pinaceae. It is a fungitoxin protecting the wood from fungal infection and also a feeding deterrent against mammals. 
Pinosylvin synthase: Enzyme able to catalyze the chemical reaction between two substrates (malonyl-CoA and cinnamoyl-CoA), and three products (CoA, pinosylvin, and $\mathrm{CO} 2)$.

Plant resistance: Range of adaptations and counter adaptations that improve plant survival and reproduction by reducing the impact of herbivores. Plants particularly use secondary metabolites that influence the behaviour, growth, or survival of herbivores. These can act as repellents or toxins to herbivores, or reduce plant digestibility. Each resistance type can be either constitutive (always present in the plant), or induced (produced in reaction to damage or stress caused by herbivores).

Pleiotropy: Pleiotropy describes the genetic effect of a single gene on multiple phenotypic traits. The underlying mechanism is that the gene codes for a product used e.g. by various cells, or that has a signalling function on various targets.

Transgenic organism: Subset of genetically modified organism GMOs, organisms that have inserted DNA originating from a different species.

PCR: Polymerase chain reaction is a technique to amplify a single or few copies of a DNA strand, generating thousands to millions of copies of a particular DNA sequence.

Risk analysis: The process including risk assessment (the science and process of estimating risk), risk management (the process of considering alternative courses of action, and selecting the most appropriate option after integrating the results of risk assessment with engineering, social, economic, and political concerns to reach a decision) and risk communication.

Environmental risk assessment, ERA: Risk assessment is the determination of the quantitative or qualitative value of risk related to a concrete situation and a recognized hazard or threat. Quantitative risk assessment requires calculations of the magnitude of the potential loss (hazard), and the probability (likelihood) that the loss will occur. Environmental Risk Assessment: the evaluation of risks to human health and the environment, whether direct or indirect, immediate or delayed (see 2001/18/EC, Annex II).

Real-time polymerase chain reaction (sometimes RT-PCR): A laboratory technique based on PCR. It enables both the detection and quantification of one or more specific sequences in a DNA sample, to detect levels of gene expression.

Unintended effect: Metabolism and/or the composition of the GM plants that may be unintentionally altered as a consequence of the genetic modification in a way that could affect plant relationships. The presence of unintended effects can be due to different reasons (e.g. pleiotropic effects) (see 2001/18/EC, EFSA 2010a). 


\section{INTRODUCTION}

\subsection{Genetically modified forest trees}

\section{Background}

The genetic modification of forest trees began nearly 30 years ago in USA, when a gene conferring herbicide tolerance was transferred to Populus (Fillatti et al. 1987).The number of studied tree species rose into the tens by the beginning of the 21 st century (Peña and Séguin 2001). The first field trials with genetically modified (GM) trees were conducted with Populus in the late 1980s (Valenzuela et al. 2006). Approximately 10 years ago, some 250 field trials with transgenic forest trees had been conducted (Robischon 2006) in Europe, North and South America, China and New Zealand (Valenzuela et al. 2006). In 2010, more than 700 field trials of GM woody plants were reported (Walter et al. 2010), and more recently, over 700 field trials of GM trees alone were reported for approval for the genetic engineering of forest trees, 500 of which occurred in the United States (Häggman et al. 2013).

The main aims of the genetic modifications of trees were initially related to marker genes and traits like herbicide and disease resistance, reproductive development and lignin biosynthesis (van Frankenhuyzen and Beardmore 2004). The target characteristics of the introduced traits later focused on three groups: growth and wood properties, insect and disease resistance and abiotic stress tolerance (Häggman et al. 2013). Modifications targeting herbivore (insect) resistance with digestive mechanisms employing Bt -toxins and digestion-hindering proteinase inhibitors (PIs) have been reported frequently (Campbell et al. 2003). Transgenic trees have also given new possibilities for both basic and applied research including lignin modification for pulp and bioethanol industry (Pilate et al. 2002; van Acker et al. 2013), soil remediation from volatile environmental pollutants (Doty et al. 2007) and restoration of threatened tree species (Merkle et al. 2007).

Populus is the first and most frequently studied tree genus in forest biotechnology (Strauss et al. 2004), and can be considered a model plant for tree genetics. Other studied tree genera include Betula, Castanea, Eucalyptus, Larix, Liquidambar, Picea, Pinus and Robinia (van Frankenhuyzen and Beardmore 2004, Valenzuela et al. 2006, Häggman et al. 2013). The first two commercial transgenic forest trees were poplars (Populus spp.). They produced Bt-toxin (from Bacillus thuringiensis) and a combination of $\mathrm{Bt}$-toxin and proteinase inhibitor to gain resistance against leaf-feeding insects. They were released to the Chinese market in 2002 and were established on commercial plantations in 2003 (Lida et al. 2003; FAO 2004; Valenzuela et al. 2006). Currently, 1.4 million Bt-modified poplars are growing in China, the oldest being 15 years old (Walter et al. 2010). Silver birch (Betula pendula Roth) in particular has been subjected to several gene modifications in Finland. These modifications aim to affect flowering (Lännenpää et al. 2005), disease resistance (Pappinen et al. 2002; Pasonen et al. 2004) and lignification (Tiimonen at al. 2005). A sugar beet chitinase gene was transferred into silver birch to possibly increase fungal disease resistance (Pappinen et al. 2002; Pasonen et al. 2004). Interestingly, chitinases are enzymes that can hydrolyse chitin, which is the main component in both fungal cell walls and insect exoskeletons (Collinge et al. 1993) raising questions about the effects of transgenic chitinase on insects (Kramer and Muthukrishnan 1997; Dahiya et al. 
2006; Shakhbazau and Kartel 2008; Arakane and Muthukrishnan 2010).

Field trials on GM trees have been established only in recent years to study ecological interactions under natural conditions. The trials have especially addressed environmental concerns such as the non-target effects on e.g. mycorrhiza (Fladung et al. 2010). Field conditions are more natural than greenhouse or laboratory conditions and therefore provide more reliable data on biotic interactions between GM trees and other organisms (Brunner et al 2007). But, in situ GM tree research is, and probably continues to be globally uncommon, due to environmental risks and safety restrictions (Strauss et al. 2009). Since the first large-scale field trials with GM trees were performed in China in the early 2000s (Lin et al. 2006), several countries are expected to follow including those in Latin America (Sedjo 2006). Despite the biosafety debate (from socioeconomic implications to environmental impacts), global and local changes in the environment and climate are likely to increase the pressure towards using GM trees especially in short-rotation tree stands (Fenning et al. 2008). Aguilera et al. (2013) predict that applications of GM trees in the EU can be expected within the next decade.

\section{Legislation}

GM trees raise not only new kinds of environmental concerns but also political conflicts (Salwasser 2004). Fladung et al. (2010) divided the environmental concerns into three groups: invasiveness, gene transfer and impacts on non-target organisms (see 1.2). Presently, the main international legal instruments concerning GM trees are the Cartagena protocol (Convention of Biological diversity 2000), World Trade Organization (SPS Agreement) and EU moratorium. No existing common international legislation specifically focuses on GM trees, but many countries have legislative processes involving transgenics (Sedjo 2010). Despite over 10 years of large-scale commercial production of GM plants, no consensus on the applied environmental risk assessment (ERA) methodologies exist (Hilbeck et al. 2011).

Presently, the EU directive 2001/18/EC (as amended later) on the "deliberate release of genetically modified organisms into the environment" regulates the non-contained use of GM organisms, also in field trials, such as ours. The directive is partly based on the Cartagena protocol. The protocol includes the precautionary principle, which means that an action should not be taken if the consequences are uncertain and potentially dangerous. In the directive, Annex II regulates the principles for the ERA, including GM plant interactions with non-target organisms. Supplementing directive Annex II, the EU commission issued decision 2002/623/EC that outlines general principles and methodology of ERA including a step-by-step approach. The following steps are defined: 1) Identification of characteristics that may cause adverse effects. 2) Evaluation of the potential consequences of each adverse effect, if it occurs. 3) Evaluation of the occurence likelihood of each identified potential adverse effect. 4) Estimation of the risk posed by each identified characteristic of the GMO(s). 5) Application of management strategies for risks originating from the deliberate release or marketing of GMO(s). 6) Determination of the overall risk of the GMO(s). The European Food Safety Authority (EFSA 2010a) later published a paper on stepwise ERA (based to 2001/18/EC) that provides guidance for assessing potential effects of GM plants on the environment.

The precautionary principle is applied in the decision-making concerning transgenic organisms because of a lack of data concerning their non-target effects (Myhr and Traavik 2002). The principle is interpreted more strictly in the EU than in the USA. In the US, risk 
assessment is based on an ecotoxicology model that focuses on chemical, not ecological impacts (Andow and Hilbeck 2004). This has led to differences in research and the state of commercialization between the two continents (Strauss et al. 2009). The main domestic legislative act regulating GM plants In Finland is the act on gene technology (Geenitekniikkalaki 377/1995, as amended later) through which directive 2001/18/EC (and the directive on contained use 2009/41/EC) has been implemented, where relevant. Still, ten years after adopting the directive, the ERA of GM organisms is interpreted very differently by different stakeholders (Hilbeck et al. 2011), probably indicating both scientific and political challenges of ERA. In their view, the current implementation of ERA falls short of complying with EU regulations, being too narrow and too close to the US model. Current EU legislation would allow for more rigorous interpretation. Aguilera et al. (2013) have recently researched the relevant EU regulatory framework addressing the risk assessment of GM trees. They concluded that when applying these regulations to GM trees some changes especially in data collection and analysis are needed. Reuter et al. (2010) called for a legal basis to regulate the coordination and harmonization of GMO monitoring in the EU and globally. Their goal is an international GMO monitoring information system (Reuter et al. 2010) including non-target species at different ecosystem levels.

In Finland the cabinet bill 246/2009 included a proposal to a parliamentary Act on transgenic agricultural production. However, later in 2011 this bill lapsed. It remains unclear how the proposal would have applied to forest trees and their field trials. However, non-target effects of GM plants on other organisms were addressed in the opinion of the select Environment Committee.

\subsection{Non-target and pleiotropic effects of transgenic trees}

The application of genetic transformation techniques in forest tree breeding is under debate. Before GM trees can be used in practical forestry, there must be a general political acceptance for them and various environmental risks have to be thoroughly studied. The ranges of ecological concerns are related to transgenic trees. The possible effects on nontarget organisms are one the most frequently mentioned threats of GM plants (e.g. Conner et al. 2003; van Frankenhuyzen and Beardmore 2004; Snow et al. 2005; Brunner et al. 2007). Non-target organisms include e.g. non-target herbivores, beneficial species as natural enemies of pests, pollinators and soil organisms (Andow and Zwahlen 2006). The non-target perspective should also extend to sublethal effects as subtle physiological and behavioral processes (e.g learning) (Desneux and Bernal 2010). The non-target perspective is essential with GM trees that interact with a broad spectrum of organisms, to reveal and minimize their effect on non-target organisms. For example in Betula and Populus, approximately 500 herbivorous insect and mite species are associated with both of the genera because of their long life-span and variable microhabitats (Brändle and Brandl 2001). GM trees may have both direct and indirect effects on other species impacting ecosystem processes like decomposition and nutrient cycling (van Frankenhuyzen and Beardmore 2004; Snow et al. 2005; Vauramo et al. 2006). Competition and population dynamics may also be affected (Snow et al. 2005). Ecological (target and non-target)

effects are hard to predict, especially in forest ecosystems because of the long life cycles of trees and their complex interactions with other organisms (van Frankenhuyzen and Beardmore 2004; Brunner et al. 2007). For improving the risk assessment of GM trees, it is essential to obtain thorough basic knowledge of the ecological interactions between GM 
trees and other organisms (Snow et al. 2005). It has recently been stated that studies at different ecological scales ranging from species to the ecosystem level are needed to gain a full understanding of the environmental effects of GM trees (Axelsson et al. 2011a; Häggman et al. 2013). As an example of unexpected effects, leaf ontogeny may have a role in the feeding preference of non-target herbivores, as found with Bt-modified poplars (Axelsson et al. 2011b). As science is still not able to predict the biochemical or toxicological effects of GM food based on knowledge of its chemical composition (Millstone et al. 1999), assessing non-target ecological effects of GM trees is even more difficult due to gaps in ecological knowledge.

The potential agricultural non-target effects of GM plants have been discussed for over 10 years (Poppy et al. 2000; Schuler et al. 2001), and recently this non-target perspective has also been applied to GM trees (Axelsson et al. 2011a,b, Post and Parry 2011). Nontarget effects are currently studied as part of a modern ERA of transgenic plants. Another principle of modern ERA (reflecting complex ecological interactions) is case-by-case, "meaning that the ERA should be carried out depending on the type of the GMOs concerned, their intended use and the potential receiving environment(s)" (2001/18/EC, annex II). The receiving environment(s) means the environment into which the GM plant will be released. It reflects the appropriate meteorological, ecological (e.g. fauna, habitats) and agricultural conditions (EFSA 2010a,b; Häggman et al. 2013). Although a case-by-case -basis in risk assessment has been adopted in risk analysis since the 1980s (Sharples 1983), non-target risk assessment of transgenic plants should focus more on the risks to local environments as suggested by Andow and Hilbeck (2004) and Andow and Zwahlen (2006). Science-based risk assessment models of non-target effects of transgenic plants have developed substantially from the 1990s. In risk assessment, risk is the probability that some adverse effect occurs duo to e.g. a transgenic plant with a transgenic product (Andow and Zwahlen 2006). The assessment of non-target effects is suggested to be based on ecological functional groups, e.g. non-target consumers and decomposers (Andow and Hilbeck 2004). Hilbeck et al. (2011) suggests that all possible effects, direct and indirect (see 1.3), cumulative and interactional should be included for improving the current ERA concept. As the number of non-target studies increases, and the questions become more complex (Hilbeck et al. 2015), it is essential to pay more attention to statistical methods to gain as many high quality results that are utilizable in ERA and even commercialization procedures as possible from the field trials (Semenov et al. 2013).

The latest non-target-reviews discuss the effects of insect-resistant GM plants to nontarget organisms (O'Callaghan et al. 2005), the effects of GM plants on soil microorganisms (Liu et al. 2005) and non-target fungi (Stefani and Hamelin 2010). Peterson et al. (2011) reviewed the non-target effects of Bt-crops on spiders. These reviews particularly addressed to the lack of knowledge concerning the taxonomy of organisms and their ecological interactions in natural conditions and the non-target effect variability of the studied organism groups. Thus Stefani and Hamelin (2010) and Liu et al. (2005) suggested a case-by-case approach for further GM studies. For example, non-target effects were found in GM plants expressing traits that were not expected to affect fungi, including traits connected to insect resistance (Stefani and Hamelin 2010). Further, none of the transgenic plants that showed deleterious effects to fungi were transformed to express anti-fungal proteins. Gatehouse et al. (2011) reviewed the non-target effects of insect-resistant GM crops, and found only few published negative effects on beneficial arthropods. 
Table 1. Published non-target effects of GM trees on non-target plant characteristics, herbivores and ecosystem structure and processes. - = No information was provided

Non-target effect on:

\begin{tabular}{lll}
\hline $\begin{array}{l}\text { GM plant / product / target } \\
\text { / reference }\end{array}$ & $\begin{array}{l}\text { Plant properties and } \\
\text { characteristics }\end{array}$ & $\begin{array}{l}\text { Herbivores } \\
\text { Ecosystem structure and }\end{array}$
\end{tabular}

B. pendula / sugar beet chitinase IV / fungal resistance / Pappinen et al. 2004

(In this case the references on the right contain results of the material originating from the above reference.)
B. pendula / 4coumarate:coenzyme A ligase (4CL) gene / lignin biosynthesis / Seppänen et al. 2007

\section{Castanea dentata /} oxalate oxidase / fungal resistance / Post and Parry 2011

\section{Reduced growth, increased stress status, changed phenology (I)}

Negative effect on
growth of
lepidoptera $O$.
antiqua especially
on high transgene
expression (III)

Negative effect on antiqua especially on high transgene expression (III)

\section{Formed normal ectomycorrhizae. Decreased percentage of mycorrhizal root tips in two lines (chit 10 and 14) (Pasonen et al. 2005).}

No effect on ectomycorrhizal colonization or the structure of fungal community (Pasonen et al. 2009).

No effect on soil biota except the distinct temporal dynamics of the mean number of nematodes in one line (chit 10) (Vauramo et al. 2006)

No changes in wood chemistry, but less root biomass and lower numbers of root tips. Formed normal ectomycorrhizas with Paxillus involutus (Batsch) Fr

Of three generalist folivores, gypsy moth (Lymantria dispar L.) grew faster on transgenic than on wild-type chestnut.

No change in phenolic compounds, $\mathrm{N}$, or $\mathrm{C}$ in the leaf litter.

Changes in the concentration of plant phenolics and nitrogen.

One GM line with changed chemical properties was less utilized by leafbeetles than the non-transgenic control.
Changes in composition of aquatic insects colonizing leaf litter, increase in insect abundance. increased biomass production / Hjältén et al. 2007 
Table 1. (cont.). Published non-target effects of GM trees on non-target plant characteristics, herbivores and ecosystem structure and processes. - = No information was provided

Non-target effect on:

\begin{tabular}{|c|c|c|c|}
\hline $\begin{array}{l}\text { GM plant / product / target } \\
\text { / reference }\end{array}$ & $\begin{array}{l}\text { Plant properties and } \\
\text { characteristics }\end{array}$ & Herbivores & $\begin{array}{l}\text { Ecosystem structure and } \\
\text { processes }\end{array}$ \\
\hline $\begin{array}{l}\text { Hybrid Populus / over- } \\
\text { expressing sucrose- } \\
\text { phosphate synthase } \\
\text { (SPS) / sucrose synthesis } \\
\text { / Hjältén et al. } 2008\end{array}$ & $\begin{array}{l}\text { Changes in the con- } \\
\text { centration of } \\
\text { condensed tannins. }\end{array}$ & $\begin{array}{l}\text { No significant } \\
\text { differences in the } \\
\text { preference of voles } \\
\text { for the different } \\
\text { poplar lines. }\end{array}$ & - \\
\hline $\begin{array}{l}\text { Populus / Bt, COMT, CAD } \\
\text { / Insect resistance, } \\
\text { reduced lignin / Hjältén et } \\
\text { al. } 2013\end{array}$ & $\begin{array}{l}\text { Changes in phenolic } \\
\text { compounds. }\end{array}$ & - & - \\
\hline $\begin{array}{l}\text { Populus / Bt toxins / } \\
\text { insect resistance / Zhang } \\
\text { et al. } 2004 \text {, Hu et al. } 2010\end{array}$ & - & - & $\begin{array}{l}\text { Changes in arthropod } \\
\text { community structure and } \\
\text { diversity: changes in } \\
\text { dominant herbivore species } \\
\text { and in densities of natural } \\
\text { enemies. }\end{array}$ \\
\hline $\begin{array}{l}\text { Populus / condensed } \\
\text { tannins } \\
\text { (proanthocyanidins) / to } \\
\text { develop a model } \\
\text { microcosm system / } \\
\text { Winder et al. } 2013\end{array}$ & - & - & $\begin{array}{l}\text { No change in bacterial or } \\
\text { fungal communities. Changes } \\
\text { that were found reflected } \\
\text { known impacts of tannins. }\end{array}$ \\
\hline $\begin{array}{l}\text { Populus alba x } P \text {. } \\
\text { glandulosa / Bt-toxin / } \\
\text { insect resistance / Zhang } \\
\text { et al. } 2011\end{array}$ & - & - & $\begin{array}{l}\text { No change in arthropod } \\
\text { community. }\end{array}$ \\
\hline
\end{tabular}

Studies on the non-target effects of GM trees at the plant-herbivore level are few (Table 1.). One transgene may have a role in other plant traits that were not targets of genetic modification (Hjälten et al. 2008) or it may have some other kind of unexpected effect. In fact, GM aspens over-expressing sucrose phosphate synthase (SPS), which is known to increase biomass production, also unintentionally induced other chemical changes that influenced the plant-herbivore interactions of the trees (Hjältén et al. 2007). In turn, PItransgenic potatoes assumed to mainly impact herbivores, also provided pathogen resistance (Quilis et al. 2007). Community and ecosystem level studies on the non-target effects of GM trees are also limited (Table 1.). Such effects can be considered 'high level consequences' (2002/623/EC) as the feeding guild structure of herbivores or the herbivorenatural enemy -dynamics can be changed. Even if the Bt poplar plantations in China seem not to cause harm to the environment in general (Walter et al. 2010), the first implications of changes in arthropod community structure and diversity have been found (Zhang et al. 
2004; Gao et al. 2006; Lin et al. 2006; Hu et al. 2010). However, Zhang et al. (2011) did not detect any effect on arthropod communities, indicating the variability of non-target effects of GM trees to arthropod communities. Leaf litter from Bt-trees is also shown to affect the composition of aquatic insect communities that colonized litter under natural stream conditions (Axelsson et al. 2011a). In terms of species composition, Bt-producing poplars had similar insect herbivore assemblages compared with control trees (Axelsson et al. 2012). Similarly, lignin-modified aspens had no effect on insect density or composition (Pilate et al. 2002; Halpin et al. 2007). Bt-producing poplars (Zhang et al. 2004) and rice (Wu et al. 2008) have impacted not only on target lepidopterans on GM plants but also on neighbouring non-transgenic plants. Outbreaks of non-target pests have also emerged as a result of the wide-scale adoption of GM plants as in case of Bt cotton ( $\mathrm{Lu}$ et al. 2010). Insect-resistant transgenic plants producing Bt toxins and proteinase inhibitors have shown to variably impact the natural enemies of herbivorous insects (Löwei et al. 2009). All these results accentuate the uncertainty concerning the type and scale of non-target effects. Lu et al. (2010) therefore addressed a critical need to predict the landscape-level impacts of GM crops. Lin et al. (2006) addressed the lack of knowledge concerning the field evaluation of the ecological risk assessment of Bt poplars. Wu et al. (2008) saw that the insect resistance of GM cotton cannot rely only on Bt (because of increased damages caused by a sucking pest), which may apply to Bt trees later. The examples above give support to the view of Hilbeck et al. (2015) according to which new GM research increases the amount of new questions, not the opposite. The studies also address the role of precautionary and case-bycase principles (see 1.1. and 1.2.).

Stability of transgene expression is a concern particularly in long-lived forest trees (Brunner et al. 2010; Ahuja 2011), but very little information is available (Fladung et al. 2013). The transgene expression level affects e.g. non-target organisms such as the herbivores of GM plants (Jouanin et al. 1998; Lachance et al. 2007) and it has to be taken into account in e.g. GMO field trials (hazard characterization) (2001/18/EC, 2002/623/EC)., Transgene expression in forest trees has appeared stable until now (Strauss et al. 2004; Klocko et al. 2014), but unintentional transgene instability in GM trees has also been reported (Fladung 1999; Jouanin et al. 2000; Kumar and Fladung 2001).Variation in gene expression (increased, reduced, lost) may depend on several reasons, e.g. gene constructs, plant species and gene transfer methods (Brunner et al. 2010).

Unintentional plant properties have frequently been found in transgenic crops modified for e.g. pest and disease resistance traits (Haslberger 2003; Yabor et al. 2010). Unintentional changes in the plant traits of GM plants have been explained by pleiotropic effects, epigenic factors, environmental factors and genetic background (Bettini et al. 2003; Haslberger 2003). Pleiotropic effects on gene expression patterns may affect plant phenotype and therefore interactions with other organisms (Hoenicka and Fladung 2006). Molecular tree improvement has been seen as an exact breeding method compared to conventional breeding because it does not affect the genetic background of a tree. Although receptive hotspots containing a relatively high percentage of AT (adenine and thymine nucleotides) value of the T-DNA integration site have been found in the host genome (e.g. Kumar and Fladung 2001), the integration of foreign DNA into plant genome is still essentially a random phenomenon (Kumar and Fladung 2002). Transgenes may hence have variable effects on "non-target" genes depending on the integration site in the host genome (e.g. Käppeli and Auberson 1998; Gutiérrez-Campos et al. 2001; Bettini et al. 2003). Transgenes per se may also have more than one function. For example, many of the chitinase genes that have been widely tested to increase plant resistance to fungal diseases 
(Emani et al. 2003; Vellice et al. 2006) are known to also have other functions (e.g. Collinge et al. 1993). A study conducted with stilbene synthase -modified strawberry has also revealed unexplainable changes possibly related to genetic modification. This study additionally showed a lack in current knowledge of plants' biochemical pathways (Hanhineva et al. 2009).

\subsection{Herbivory and herbivore resistance in trees}

Silver birch (Betula pendula) is commercially the most important deciduous tree species in Finland. Numerous insect and mammalian herbivores feed on birch (Saalas 1949; Laitinen et al. 2002; Silfver et al. 2014). Herbivorous insects cause damage to foliage and wood depending on their feeding habit/guild (Peeters et al. 2001). In birch, the main guilds are leaf chewers, leaf miners, sucking insects (sap-feeders) (e.g. leaf aphids) and stem miners like Phytobia betulae E.Kang. The first group includes e.g. lepidopteran and hymenopteran larvae, and coleopteran larvae and adults (e.g. Chrysomelidae). Aspen (Populus sp.) is considered an ecologically important keystone species of boreal ecosystems, because it sustains a very high number of animals and fungi (Myking et al. 2011). Generally, insect feeding guilds differ in their stress responses (Larsson 1989) and (reflecting insect orders) tend to have a different peritrophic matrix (layer of chitin and protein lining the midgut of most invertebrates), which acts as a physical barrier against abrasive food particles, digestive enzymes, and pathogens (Hegedus et al. 2009).

Herbivores cause stress to trees and reduce their growth and wood quality (Kulman 1971; Ylioja et al. 1998; Kullberg and Bergström 2001; Lyytikäinen-Saarenmaa and Tomppo 2002; Zvereva et al. 2010). Stress can be seen as increased crown transparency or decreased stem growth. If stress continues, the capability of a tree to overcome further stress or to survive diminishes (Dobbertin 2005). In silver birch, larval tunnels of $P$. betulae in the cambium are one of the most important factors decreasing wood quality (Ylioja et al. 1998). The species prefers fast-growing trees (Ylioja et al. 1999), but does not affect tree growth (Ylioja et al. 1998). A trade-off is suggested to exist between plant growth and resistance. The balance is based on the fact that the same carbon resources are used in growth and defence processes (Herms and Mattson 1992). If a transgene affects tree growth, the patterns of plant defense may also be changed, or vice versa.

Herbivore performance is largely based on host plant quality (Awmack and Leather 2002; Iason 2005). Intra-species plant quality is essentially dependent on growing site and light conditions that are reflected in the nutrient allocation $(\mathrm{C}, \mathrm{N})$ and secondary metabolites (that are produced in resistance reactions) of plants. Siver birch has been shown to have substantial genotypic variation in resistance to insect herbivores (Silfver et al. 2009), and against mammals (as the amount of resin droplets) (Mutikainen et al. 2000). Trees have developed several resistance mechanisms against insect and mammalian herbivores (Howe and Jander 2008). The main resistance type is chemical resistance that is based on secondary chemicals (Walling 2000; Iason 2005; Dearing et al. 2006). For example bark glands in silver birch branches produce triterpenoids that deter mammalian feeding, and terpenoids in leaves impair the feeding of lepidopterans (Tahvanainen 1991; Haukioja 2003). The results of the unexpected effects of genetic engineering on plant secondary metabolism, i.e. plant defense were found in a transgenic potato expressing insecticidal proteins (Birch et al. 2002). Plant quality is also dependent on seasonal changes in leaves (Feeny 1970). Because of these changes insect larvae have restricted timespace to 
find suitable foliage. The synchrony between insect hatching and budburst is critical for the performance of herbivores. This synchrony seems to be inherited and a result of adaptation (Tikkanen and Lyytikäinen-Saarenmaa 2002; van Asch and Visser 2007). Genetic modification (e.g. glyphosate resistance) may cause changes in this phenological window (Bautista et al. 2010), which may affect insect herbivore performance.

Herbivore resistance to a plant individual (genotype) depends on genetic and environmental factors (e.g. Prittinen et al. 2003). The resistance trees show against insect herbivores may be continuous/constitutive or induced after attack (Haukioja 1990). Induced resistance reactions may impact both the tree and the insect feeding on it (Nykänen and Koricheva 2004). The wounding treatment has been used to mimic herbivore feeding, although it may also induce reactions that are not identical to insect feeding (Hjältén 2004; Lehtilä and Boalt 2004; Howe and Jander 2008). This multifunctional treatment has also been applied to study the impacts of climate change on herbivore feeding and the palatability of (non-GM) birch (Huttunen et al. 2008).

Complex interactions between herbivores and pathogens in plants affect both parties (Stout et al. 2006) at the ecological and physiological level (Walling 2000). Pathogens and herbivores have co-evolved direct and indirect interactions by sharing the same environment. Indirect interactions between pathogens and herbivores occur when infection or infestation by a first attacker alters the host plant quality that affects a second attacker (Stout et al. 2006). Most studies on plant-herbivore-pathogen-interactions have been conducted with herbaceous plants and insect herbivores (Rostás et al. 2003). Some studies have been conducted with Betula trees and their herbivores with variable results. Rust fungus (biotrophic) Melampsoridium betulinum (Pers.) Kleb. had an indirect negative effect on Epirrita autumnata Borkhausen larvae (Lappalainen et al. 1995). In contrary, performance of birch aphids (Euceraphis betulae Koch) reared on a (necrotrophic) leaf spot pathogen (Marssonina betulae (Lib.) Magnus) -infected leaves correlated positively with the infection level (Johnson et al. 2003). The interaction was most likely plant-mediated, as the fungus and aphid were spatially separated. It illustrated the importance of plantmediated indirect effects in phytophagous insect communities. Interaction with herbivore and pathogen resistance has been found in defense reaction pathways of plants: the pathways triggered by insect and fungi overlap (Walling 2000) e.g. in a way that the first attack enhances the plant's ability to resist a second attacker. This may lead to a bidirectional detrimental effect as shown with aphids (Rhodobium porosum Sanderson) and (nectotrophic) fungus (Botrytis cinerea (De Bary) Whetzel) sharing the rose as host plant (Mouttet et al. 2011). Such plant-mediated indirect interactions can impact both pathogen and herbivore population dynamics (Mouttet et. al. 2011).

\subsection{The potential effects of chitinase and pinosylvin on herbivores}

Chitinases (Enzyme Commission number 3.2.1.14) are enzymes that catalyze the hydrolysis of chitin, the linear polymer of $\beta$-1,4-linked N-acetylglucosamines, which is the main component of fungal cell wall, insect exoskeleton (Collinge et al. 1993; Kasprzewska 2003) and insect peritrophic matrices (see 1.3.) (Hegedus et al. 2009). In plants, the antifungal role of chitinases has been shown in transgenic plants producing chitinase (Dahiya et al. 2006). Chitinases also have roles in plants' physiological events linked to growth and development (Kasprzewska 2003). The wounding treatment also induces chitinase production in poplar (Christopher et al. 2004). In insects, the main function of chitinases is 
the turnover of chitin-containing extracellular matrices such as the insect cuticle and the peritrophic matrix during moulting. Chitinases probably additionally have a digestive function in both insects and vertebrates including mammals (Dahiya et al. 2006; Bussink et al. 2007; Arakane and Muthukrishnan 2010).

Trees defend themselves against insect herbivores and fungal pathogens by producing defensive compounds. Insect and disease resistance of trees is likely to be controlled by many genes with additive effects producing general and specific signals (von Weissenberg 1990; Walling 2000). Generally, plant responses to herbivory are less understood compared to plant responses to pathogens (Howe and Jander 2008). Chitinases are among the most frequently studied defencive products found in plants, animals, fungi and microbes (Collinge et al. 1993; Lohtander et al. 2008). In trees, chitinases are expressed during various abiotic and biotic agents as pathogens and insect pests (Veluthakkal et al. 2012). Reviews concerning chitinase expression in trees are limited compared to annual plants. However, it seems that chitinase gene families are larger in trees compared to short-lived herbaceous species (Veluthakkal et al. 2012). The transferred chitinase gene used in this thesis is native to sugar beets and possesses high molecular similarity with a birch-native chitinase gene identified from the birch EST-library (a library of short sub-sequences of cDNA sequences) (Lohtander et al. 2008). The constitutive expression of a transgenic chitinase IV gene can consequently disturb the functioning of the silver birch's own endogeneous chitinase genes (Niskanen et al. 2011). Transgenes may also interact, e.g. silence (see 1.2.) genes in the plant genome.

Chitinase transgenes have been transferred to tobacco, potato and rape to study the possibilities of improving plant resistance against insects (Schuler et al. 1998; Arakane and Muthukrishnan 2010). The effects of transgenic chitinases originating from plants and insects on insect performance have been variable: Coleopteran chitinase had a positive effect on aphids (Myzus persicae Sulzer) as improved parameters related to aphid population growth (Saguez et al. 2005) and bean chitinase had negative effects on aphids (Aulacorthum solani Kaltenbach) as reduction in fecundity (Down, R. E., as referred to by Gatehouse and Gatehouse 1998). No effect of bean chitinase on aphid (M. Persicae) fecundity (Gatehouse et al. 1996) or on lepidopteran (Lacanobia oleracea L.) biomass or larval survival (Gatehouse et al. 1997) were found. Transgenic plants producing chitinases originating from a plant (Wang et al. 2005; Lawrence and Novak 2006), insect (Ding et al. 1998), and virus (Corrado et al. 2008; Fiandra et al. 2010) have been shown to be harmful to insects. Tobacco-producing viral chitinase has shown antifungal (against B. cinerea) and insecticidal properties against lepidopteran (Bombyx mori L., Heliothis virescens Fabricius) larvae but no effect has been observed on aphids (M. persicae) (Corrado et al. 2008). Orally administered chitinase has also increased the larval mortality rate and reduced the growth of lepidopteran B. mori (Rao et al. 2004). When combining the insect chitinase gene with a scorpion toxin gene, the resistance increased more against lepidopterans. The mortality of B. mori larva was up to $100 \%$ (Wang et al. 2005) and most of the larvae of Hyphantria cunea Drury could not pupate (Yang 2008). This resistance was not increased against cerambycid Anoplophora glabripennis Motschulsky (Yang 2008). Potential impacts of transgenic chitinases on different organism groups have been reviewed during the 1990s including only Lepidoptera and Homoptera representing less than 10 species (Schuler et al. 1998; Tzfira et al. 1998). In terms of directive 2001/18/EC, the expression of chitinase and pinosylvin synthase (described below) are the studied novel traits.

Stilbenes are plant defense compounds against pathogens and herbivores that participate in both constitutive and inducible defense mechanisms, but the detailed functions are not 
clear. However, they play a role in plant-pathogen and plant-herbivore relationships (Chong et al. 2009). They are produced by species from a number of unrelated gymnosperm and angiosperm plants, including the woody families Pinaceae, Vitaceae, and Betulaceae (Chong et al. 2009). Stilbenes are products of the phenylpropanoid pathway and are often produced in plants as stress metabolites and agents of constitutive defensives in lignified tissues (Hart 1981). Stilben biosynthesis is enhanced by fungal infection (Hammerbacher et al. 2011). The effects of a stilbene synthase-encoding gene on pathogenic and decay fungi have been studied in in vitro (in an artificial environment) aspens by Seppänen et al. (2004). Constitutively produced stilbenes act as deterrents of herbivores in several plant species (Chong et al. 2009). Stilbene pinosylvin is toxic e.g. to fungi (Hart 1981), but the toxicity is compromized (Chong et al. 2009). Pinosylvin itself has been shown to suppress the browsing of pines (Sullivan et al. 1992) and alders (Clausen et al. 1986) by hares. Furthermore, pinosylvin has been shown to operate as a feeding deterrent of leafrollers Ctenopsteustis obliquana Walker and Epiphyas postvittana Walker (Russell et al. 2000) but not the bark beetle Ips paraconfusus Lanier (McNee et al. 2003). The varying results between these herbivores address the variety of potential non-target effects of the studied transgenic material on herbivores.

\subsection{Feeding trials on transgenic trees}

Since developing the first insect-resistant trees, feeding trials have also been conducted with trees modified to express other traits than insect resistance. The genetic modification of insect-resistant trees began with trees producing Bt toxin (Dandekar et al. 1994; Shin et al. 1994). Transgenes producing digestive enzymes and inhibitory proteins have also been tested to interfere with the digestive systems of insects (Schuler et al. 1998). Feeding trials have been conducted mainly with broadleaved trees and lepidopteran and coleopteran larvae (Schuler et al. 1998; Tzfira et al. 1998; Poupin and Arce-Johnson 2005). The forest tree species used in the feeding experiments have included broadleaved trees such as aspen (Kang et al. 1997; Pilate 2002; Barbehenn et al. 2007), birch (Tiimonen et al. 2005; Wang et al. 2007) and eucalyptus (Harcourt et al. 2000), and conifer trees such as larch (Shin et al. 1994), spruce (Ellis et al. 1993) and pine (Tang and Tian 2003). The results of the feeding trials have shown that different types of transgenes produce different levels of resistance. The Bt toxins produced by poplars have caused a strong resistance against lepidopterans including $O$. antiqua (Yang et al. 2003; Cao et al. 2010). Instead, modification of the lignin biosynthesis pathway in aspen did not lead to different feeding preferences of insects (Tiimonen et al. 2005) or differences in damages caused by insects (Pilate 2002). In the first feeding trial with transgenic tree material and mammalian herbivores, the preference of voles fed with transgenic hybrid poplars (Populus tremula $\mathrm{x}$ tremuloides) (over-)expressing sucrose-phosphate synthase was not affected compared to control plants (Hjältén et al. 2008).

Feeding trials with transgenic tree material genetically modified for pathogen resistance have not been previously conducted either with insect or mammalian herbivores. However, inhibition of the development of Colorado potato beetle larvae was observed in a feeding experiment with transgenic tobacco expressing poplar chitinase when the larvae were fed with the transgenic plant material (Lawrence and Novak 2006). This poplar chitinase gene was previously induced during the infestation of a lepidopteran herbivore (Clarke et al. 1998). Chitinase may contrastingly have a positive effect on aphid performance (Saquez et 
al. 2005). Feeding experiments with transgenic forest trees and mammal herbivores provide important information for ERA because mammals have a significant role in forest ecosystems as modifiers of vegetation and cyclers of nutrients into soil. Despite this only two feeding studies with GM forest trees and mammals has been conducted in addition to our study (IV) (Hjältén et al. 2008; Yang et al. 2013).

From the herbivore viewpoint, many aspects address the importance for further knowledge of ecological interactions between GM trees genetically modified for pathogen resistance and other organisms. Firstly, the interaction between herbivores and pathogens in forest ecosystems is constant and complex (Rostas et al. 2003). Secondly, GM plants desired and the found impact may differ: plants genetically modified against fungi can affect insect herbivores and vice versa (Stefani and Hamelin 2010). When the studied GM trees affect plant-fungi-interactions as changed fungal disease resistance, and fungi affect herbivores through herbivore-fungi-interaction, GM trees are likely to have indirect (fungal mediated) influences on herbivores. Interaction is likely because both chitinase and pinosylvin are expected to affect fungi and herbivores. To study the non-target effects of the GM trees producing chitinase and pinosylvin synthases, field trials represent close-tonatural conditions and the studied herbivore species represent a functional group of primary consumers in the boreal forest environment (based to 2001/18EC, see also Andow and Hilbeck 2004).

\section{AIMS OF THE STUDY}

The main aim of this thesis was to provide information on the non-target effects of genetic modifications for fungal disease resistance on the interactions between GM trees and herbivores.

From the viewpoint of GM-tree risk assessment, the aim of this study was to evaluate the potential adverse (indirect, non-target) effects of GM trees on herbivore performance during a field trial and to produce information for the needs of risk analyses.

The following specific goals for the research were defined as:

1) To reveal the potential pleiotropic effects of the sugar beet chitinase IV gene in transgenic birch lines that might influence herbivore performance, through traits related to growth, quality, stress status and leaf phenology. (I)

2) To test for differences in herbivore pressure (species composition, density and visible damage) between transgenic birch lines carrying the sugar beet chitinase IV gene and corresponding control (isogenic) as well as other wild-type birch genotypes. (II)

3) To study the differences in the feeding performance of insect herbivores between chitinase transgenic and corresponding control (isogenic) birches. Also, to test for rapidly induced resistance reactions between chitinase transgenic lines and a corresponding control. And to determine whether these reactions influence the performance of insect herbivores and the growth responses of a branch. (III) 
4) To determine whether genetic modification of birch and aspen for fungal disease resistance will influence their palatability to roe deer and mountain hare in the winter. (IV)

\section{MATERIAL AND METHODS}

\subsection{Plant material and field trial}

A more detailed description of the material and methods used are given in the original papers/ manuscripts I - IV, or in the original articles cited in them. The used tree material and studied herbivores are found in Table 2.

To study tree growth, quality, stress and phenology (I), insect density and composition (II), lepidopteran feeding and growth (III) and the feeding preference of mammals (IV), transgenic silver birch lines (chit1-15) carrying the sugar beet chitinase IV gene and their corresponding non-transgenic (isogenic) control (JR1/4) were used. For more information on gene transfer and characteristics of the transgenic lines, see e.g. Pappinen et al. 2002. Seven other non-transgenic (= wild-type) birch clones were also included in the studies (II) to represent natural variation in herbivore resistance in the field trial. The field trial was established in 2000 as a randomized block design consisting of 15 blocks, each containing one replicate of each plant type. Each block had 15 different chitinase transgenic plant lines, one corresponding control (isogenic wild-type clone) and seven other non-transgenic wild-type clones. The chitinase transgenic lines were grouped into three categories depending on the level of the transgene expression measured as chitinase IV transcript accumulation (Pasonen et al. 2004). The field trial data was collected in 2002 (measurements for tree growth, visual classification for phenology and general condition (I)) and 2003 (measurements for tree growth, visual classification for phenology and general condition (I), wood disk data for P. betulae (I), branch measurements for insect density, visual classification for insect fauna and leaf damages (II), branch measurements for the wounding study (III), leaves for $O$. antiqua feeding study (III), branches for the $L$. timidus feeding study (IV) (Table 2.)). Tree height varied between 1-2 $\mathrm{m}$ at the time of the harvest in August-September 2003. In terms of the directive 2001/18/EC, B. pendula and Populus sp. are the studied crop plants, and the receiving environment (see 1.2.) is the field trial area that is described in more detail in $\mathbf{I}$.

Greenhouse-grown transgenic birch lines were used to study the growth and feeding of P. bucephala (III) and the feeding preferences of C. capreolus (IV). Greenhouse-grown transgenic aspen and hybrid aspen lines were used to study the feeding preferences of $L$. timidus (IV), (Table 2.). Transgenic aspen and hybrid aspen lines were confirmed to accumulate pinosylvin synthase specific mRNA and to show stilbene synthase enzyme activity in vitro (Seppänen et al. 2004). The aspen material for the feeding trials with $L$. timidus (IV) was collected from the greenhouse-grown five-years-old aspen trees during winter 2003 (Table 2.). 


\subsection{Molecular and biochemical studies}

Sugar beet chitinase IV expression was studied using Northern hybridization as the level of mRNA accumulation during the last growing season of the field trial trees (Pasonen et al. 2004). Data (branch measurements for insect density, visual classification for insect fauna and leaf damages) were concurrently collected from the field trial for study II and plant material was collected for the feeding studies with $O$. antiqua (III) and the mammals (IV).

Table 2. Summary of the herbivore and tree species, and the study methods used in the thesis.

\begin{tabular}{|c|c|c|c|c|c|c|}
\hline Herbivores & $\begin{array}{l}\text { Tree } \\
\text { species }\end{array}$ & Transgene & $\begin{array}{l}\text { Plant } \\
\text { material } \\
\text { was } \\
\text { grown in }\end{array}$ & Study site & Response variable & $\begin{array}{l}\text { Paper } \\
\text { number }\end{array}$ \\
\hline $\begin{array}{l}\text { Birch } \\
\text { cambium fly } \\
\text { Phytobia } \\
\text { betulae }\end{array}$ & $\begin{array}{l}\text { Silver birch } \\
\text { Betula } \\
\text { pendula }\end{array}$ & $\begin{array}{l}\text { Chitinase } \\
\text { IV from } \\
\text { sugar beet }\end{array}$ & Field trial & $\begin{array}{l}\text { Field trial, } \\
\text { Viikki campus }\end{array}$ & Occurrence & I \\
\hline Insect fauna & $\begin{array}{l}\text { Silver birch } \\
\text { B. pendula }\end{array}$ & $\begin{array}{l}\text { Chitinase } \\
\text { IV from } \\
\text { sugar beet }\end{array}$ & Field trial & $\begin{array}{l}\text { Field trial, } \\
\text { Viikki campus }\end{array}$ & $\begin{array}{l}\text { Insect density } \\
\text { (number/branch meter) } \\
\text { Insect orders (number) } \\
\text { Leaf damage types } \\
\text { (number) } \\
\text { Vertical/horizontal } \\
\text { variation of insects }\end{array}$ & II \\
\hline $\begin{array}{l}\text { Rusty } \\
\text { tussock moth } \\
\text { Orgyia } \\
\text { antiqua }\end{array}$ & $\begin{array}{l}\text { Silver birch } \\
\text { B. pendula }\end{array}$ & $\begin{array}{l}\text { Chitinase } \\
\text { IV from } \\
\text { sugar beet }\end{array}$ & Field trial & $\begin{array}{l}\text { Laboratory, } \\
\text { Viikki campus }\end{array}$ & $\begin{array}{l}\text { Growth and feeding } \\
\text { indices (RGR, RCR, } \\
\text { ECD,AD,ECI), survival) } \\
\text { Branch growth response } \\
\text { after wounding }\end{array}$ & III \\
\hline $\begin{array}{l}\text { Buff-tip } \\
\text { Phalera } \\
\text { bucephala }\end{array}$ & $\begin{array}{l}\text { Silver birch } \\
\text { B. pendula }\end{array}$ & $\begin{array}{l}\text { Chitinase } \\
\text { IV from } \\
\text { sugar beet }\end{array}$ & $\begin{array}{l}\text { Green- } \\
\text { house }\end{array}$ & $\begin{array}{l}\text { Laboratory, } \\
\text { Viikki campus }\end{array}$ & $\begin{array}{l}\text { Growth and feeding } \\
\text { indices (RGR, RCR, } \\
E C D, A D, E C l), \text { survival) }\end{array}$ & III \\
\hline $\begin{array}{l}\text { Roe deer } \\
\text { Capreolus } \\
\text { capreolus }\end{array}$ & $\begin{array}{l}\text { Silver birch } \\
\text { B. pendula }\end{array}$ & $\begin{array}{l}\text { Chitinase } \\
\text { IV from } \\
\text { sugar beet }\end{array}$ & $\begin{array}{l}\text { Green- } \\
\text { house }\end{array}$ & $\begin{array}{l}\text { Ähtäri Zoo, } \\
\text { Fenced test } \\
\text { site }\end{array}$ & $\begin{array}{l}\text { Proportion of mass } \\
\text { consumed } \\
\text { Height loss } \\
\text { Branch loss } \\
\text { Soluble sugars } \\
\text { Starch }\end{array}$ & IV \\
\hline $\begin{array}{l}\text { Mountain } \\
\text { hare } \\
\text { Lepus } \\
\text { timidus }\end{array}$ & $\begin{array}{l}\text { Silver birch } \\
\text { B. pendula }\end{array}$ & $\begin{array}{l}\text { Chitinase } \\
\text { IV from } \\
\text { sugar beet }\end{array}$ & Field trial & $\begin{array}{l}\text { Mekrijärvi } \\
\text { research } \\
\text { station, } \\
\text { indoor cage }\end{array}$ & $\begin{array}{l}\text { Proportion of mass } \\
\text { consumed } \\
\text { Palatability indices }\end{array}$ & IV \\
\hline $\begin{array}{l}\text { Mountain } \\
\text { hare } \\
\text { L. timidus }\end{array}$ & $\begin{array}{l}\text { Aspen } \\
\text { Populus } \\
\text { tremula }\end{array}$ & $\begin{array}{l}\text { Pinosylvin } \\
\text { synthase } \\
\text { from Scots } \\
\text { pine }\end{array}$ & $\begin{array}{l}\text { Green- } \\
\text { house }\end{array}$ & $\begin{array}{l}\text { Mekrijärvi } \\
\text { research } \\
\text { station, } \\
\text { indoor cage }\end{array}$ & $\begin{array}{l}\text { Proportion of mass } \\
\text { consumed } \\
\text { Palatability indices }\end{array}$ & IV \\
\hline $\begin{array}{l}\text { Mountain } \\
\text { hare } \\
\text { L. timidus }\end{array}$ & $\begin{array}{l}\text { Hybrid } \\
\text { aspen } \\
\text { Populus } \\
\text { tremula } x \\
\text { tremuloides }\end{array}$ & $\begin{array}{l}\text { Pinosylvin } \\
\text { synthase } \\
\text { from Scots } \\
\text { pine }\end{array}$ & $\begin{array}{l}\text { Green- } \\
\text { house }\end{array}$ & $\begin{array}{l}\text { Mekrijärvi } \\
\text { research } \\
\text { station, } \\
\text { indoor cage }\end{array}$ & $\begin{array}{l}\text { Proportion of mass } \\
\text { consumed } \\
\text { Palatability indices }\end{array}$ & IV \\
\hline
\end{tabular}


Enzyme activity test and reverse transcription PCR (RT-PCR) were used to determine the chitinase activity and the expression of the sugar beet chitinase IV transgene In the $P$. bucephala feeding experiment (Chang et al. 1993; Bolar et al. 2000).

In the feeding trial with roe deer (IV), sugar and starch analyses of the transgenic birch material were conducted to determine the nutritional quality of GM trees and to test for possible unintentional effects on plant chemical composition of the transgene introduction. The analyses were conducted according to the $\mathrm{HClO} 4$ extraction procedure (Hansen and Møller 1975). A Perkin Elmer Lambda 11 spectrophotometer was used in both analyses.

\subsection{Tree growth and quality}

Tree growth was assessed as tree height $(\mathrm{m})$ and basal diameter $(\mathrm{cm})$, measured at the end of the growing season in 2002 and 2003. The stress status of the trees was assessed by leaf colour in the middle of the growing season (leaf colour index) at the scale from 1 to 4 ( $1=$ green, $2=$ green/yellow, $3=$ green/yellow/red, $4=$ yellow $/$ red). The amount of red colour in the leaves is suggested to correlate with the stress status of the tree (Hoch et al. 2001). Leaf phenology for the different clones was determined based on bud burst dates and the development of autumn colours. Bud burst was assessed on a scale from 1 to $6(1=$ buds closed and brown, $6=$ leaves open) and the development of autumn colours on a scale from 1 to $5(1=$ no yellow leaves, $5=$ all leaves yellow $)$. The general condition of the trees was assessed based on the visual appearance of the trees in the autumn of 2003 on a scale from 1 to 3 ( 1 = partly dead, many brown leaves, 3 = healthy, green leaves) (I).

To determine wood quality, the tree ring growth of the last three years $(2003,2002$, 2001) was measured and the tree rings were classified as either containing or not containing larval tunnels of $P$. betulae. The feeding of this wood-mining herbivorous insect causes feeding scars that decrease birch wood value (Ylioja et al. 1998). The occurrence of the species was measured using wood disks (one per tree) cut from the base of the stems. Depending on the occurrence of larval tunnels on the disks, the trees were classified into two groups: those that contained tunnels and those that did not.

\subsection{Insect density and composition}

Insect density was measured to study insect herbivore pressure between chitinase transgenic lines, a corresponding (isogenic) control and other wild type trees. Insect density was determined by measuring branch length and counting the number of insects per one branch metre. The branches were divided horizontally and vertically into three sections to study vertical and horizontal variation in insect density, composition and insect-caused leaf damages. The insects were grouped into orders and further into families if they were abundant, as e.g Coccinellidae, based on a pilot study. Leaf damages were grouped (based on insect feeding guilds) into leaf chewing, leaf mining, gall, leaf roll, web formation, leaves glued together, and sucking damage (modified from Saalas 1949, Annila 1987, Peeters 2002) (Figure 1.). The leaf damage level was first measured visually using a scale from 0 to $4(0=$ undamaged leaves, $4=$ complete damage of the leaves $)$, but later the five levels were pooled into two groups (damage/no damage), because level 3 and 4 herbivory was, contrary to what was expected, very rarely found. The number of studied branches per tree was $6.7 \pm 3.3($ mean $\pm \mathrm{SD})$. 


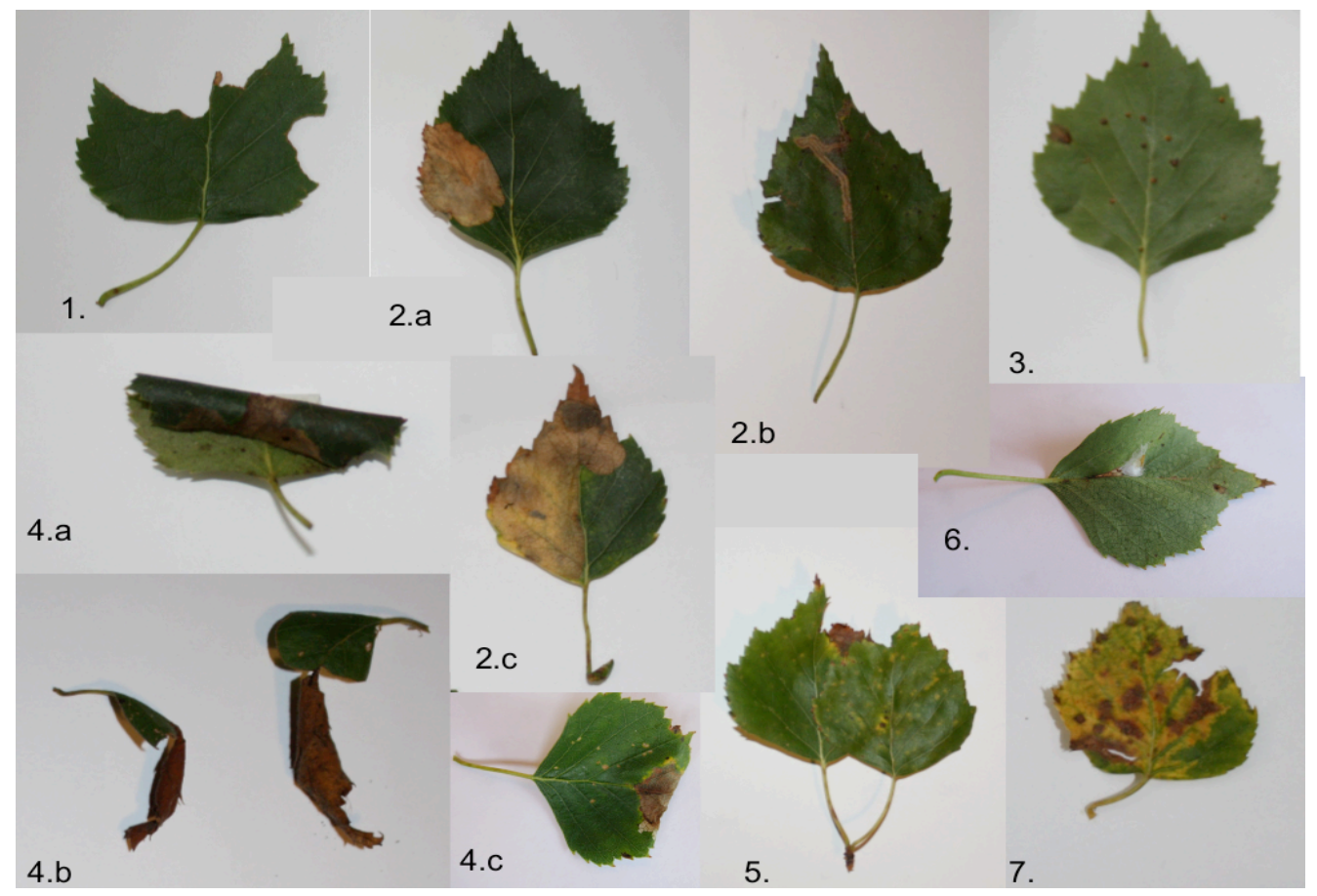

Figure 1. Examples of leaf damage types.

$1=$ chewing,

$2=$ mining $(a, c$, blotch,$b$ tunnel),

$3=$ gall,

$4=$ roll $(a, c$ longitudinal, $b$ leaf cone $)$,

$5=$ web formation,

$6=$ glued together,

7 = sucking damage. Photo: L.Vihervuori

\subsection{Feeding trials with insects and mammals}

Feeding trials were conducted with generalist insect and mammalian herbivore species common in Finland to determine whether GM modification of birch and aspen affected their palatability to herbivores (see Table 2.). The studied insect species were rusty tussock moth (Orgyia antiqua L.) and buff-tip (Phalera bucephala L.), moths from the families Lymantriidae and Notodontiidae, respectively (Figure 2.). Both species are generalist leaf feeding lepidopterans occurring especially on deciduous trees and shrubs (Seppänen 1970). The studied mammalian species roe deer (Capreolus capreolus Gray) and mountain hare (Lepus timidus L.) are common herbivores on birch and aspen using tree branches as winter food in boreal forests (e.g. Bryant et al. 1983). No-choice feeding trials with insects were 

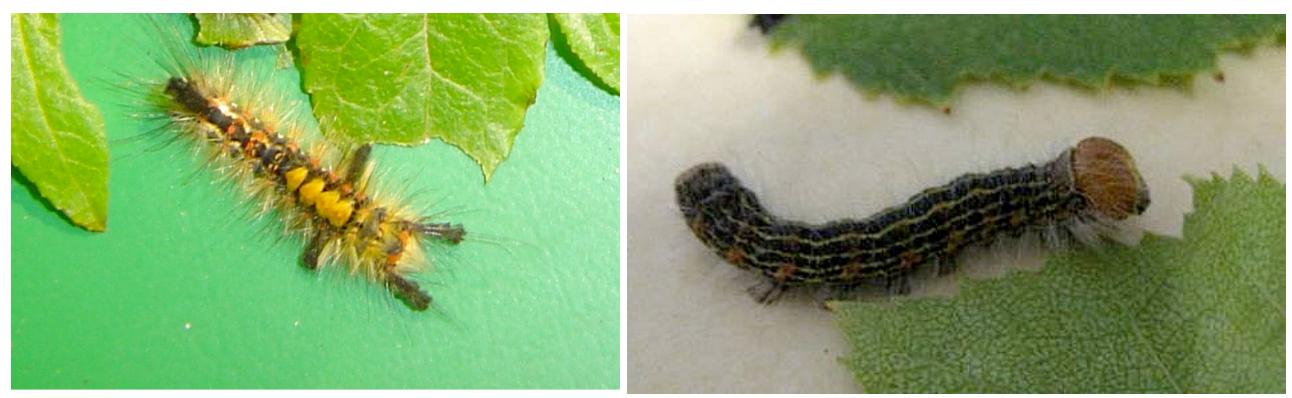

Figure 2. The lepidopteran species used in the feeding trials: Orgyia antiqua (left), Phalera bucephala (right). Photos: L.Vihervuori

conducted in a growing chamber. The groups (O. antiqua 56, $P$. bucephala 20$)$ of larvae were fed transgenic or non-transgenic leaf material (O. antiqua 7 days, P. bucephala 10 days, until the larvae began pupating). Mammal feeding trials were conducted as cafeteria tests with a choice between transgenic and non-transgenic material (whole seedlings for $C$. capreolus, branch twigs for L. timidus). The measured consumption variables for all the feeding trials are listed in Table 2.

To study whether the GM modification of birch affected its responses to simulated herbivory, a wounding treatment was used to measure 1) the effect of wounding on plant growth and 2 ) on larval growth $(O$. antiqua). Induced responses were studied by wounding leaves of field-grown trees.

The field study with chitinase transgenic silver birch (Pasonen et al. 2004, as well as studies I, II, III, IV) were carried out with the permission of the Board of Gene Technology, ministry of Social and Health Affairs (notification no. 2/MB/00). All experiments (I, II, III, IV) were performed in compliance with current Finnish laws. The feeding experiments were approved by the Board of Gene Technology and conducted in accordance with EU directive (2001/18/EC) concerning the safe handling of GM material (see 1.1).

\section{RESULTS AND DISCUSSION}

\subsection{The impact of transgenes on tree growth and quality}

\section{Impact of the sugar beet chitinase IV transgene to tree growth properties (I)}

A negative impact of sugar beet chitinase IV on tree height growth was found (I) (Table 3.). The effect may be caused by transgenic chitinase, because chitinases regulate plant processes of growth and development (Kazsprewska 2003). An unintentional effect on plant height, diameter, and the crown height has recently been found in pineapple expressing transgenic chitinase (Yabor et al. 2010). The effect was explained by in vitro culture properties that produce rejuvenation (development of juvenile morphological characters on mature explants $=$ cultured in vitro) and epigenetic changes. It appear that wood production is delayed when aiming to increase disease resistance through the chitinase transgene. 
Impact of the sugar beet chitinase IV transgene to tree quality properties (II)

Tree quality (performance) was also negatively affected in the field trial with chitinase transgenic silver birch, e.g. the stress status increased (increased levels of red colour and decreased general condition measured as the number of branches, loss of apical dominance and frost damages) (I) on transgenic lines compared to non-transgenic wild-type control trees. The colour change may be explained by the elevated stress status of the trees (Hoch et al. 2001). GM plants have also earlier shown unexpected colours and photosynthetic characteristics (Sun et al. 2009; Pons et al. 2012) that have been explained by changes in the expression mechanisms of photosynthetic regulation genes and by temporal-specific expression of the transgenes (Sun et al. 2009). The leaves of B. pendula turn to yellow in autumn and red leaf colour can be connected to youth (Archetti et al. 2009) or stress, where anthocyanin production may be induced by a variety of environmental reasons (Hoch et al. 2001). When combining increased red leaf colour, other stress symptoms, and reduced growth, the chitinase transgenic birches could have been so stressed that their development was inhibited. High densities of aphids may have lowered their quality even more by sucking nutrients and sugars (Zvereva et al. 2010, see also 4.2.). Red leaf colour acts as a warning signal towards insects in the coevolution hypothesis (Archetti et al. 2009) (see also 4.2. coevolution hypothesis between aphids and yellowing leaves). Red colour (antocyanins) in the leaves may provide a visual cue to herbivores of the presence of harmful compounds (Close and Beadle 2003) such as phenolics (Karageorgou et al. 2008). Aphids and other insect herbivores usually prefer green and yellow to red leaves (Archetti et al. 2009, White 2009). Despite the possible visual cues, aphids in our study were abundant in the reddish leaves of transgenic lines expressing high levels of chitinase. As stress-specialists (see 4.2), some stress-related property (e.g. higher amounts of soluble nitrogen or volatile profile) in the leaves may have been too attractive to them despite the increased level of chitinase (and possibly other chemical defense compounds). The same leaf properties may also partly explain the lower performance of $O$. antiqua.

Phenological phases, such as bud burst and leaf senescence were delayed in chitinase transgenic birch lines (I). These changes may result from changes in plant hormones (Fladung et al. 1997). Even small changes in plant phenology may lead to considerable effects on herbivores (van Asch and Visser 2007). A recent study by Sinkkonen et al. (2012) found that silver birch's autumn leaf colouration showed significant genetic variation. The results also suggested that genotypes expressing strongest leaf colour reflectance were subjected to more egg-laying by E. betulae (Sinkkonen et al. 2012). The phenology of GM trees is poorly known. However, genetic modification of poplars in a long-term field trial did not result in any phenological differences (Pilate et al. 2002). The variability between the two results addresses the need for a case-by-case approach. The occurrence of the stem miner Phytobia betulae Kang did not differ between chitinase transgenic trees and control trees (I). The density of $P$. betulae correlated positively with the trees' growth rate but not directly with the transgenic status of the trees. All these nontarget changes may affect herbivores directly (changes in phenology may affect the survival of lepidopteran herbivores (e.g. Feeny 1970; Foster et al. 2013)) and indirectly (changes in leaf colour and senescence may affect aphid preference (Holopainen et al. 2009)).

The unintended phenotype changes (I) in transgenic birches may be explained by transformation-induced mutations occuring when an inserted transgene disrupts the sequence of the endogenous plant DNA (Wilson et al. 2006). An unintended phenotype can 
also result from epigenetic or environmental factors, or the genetic background in which a trait is expressed (Haslberger 2003). The changed pathogen pressure in chitinase transgenic trees compared to the control (Pasonen et al. 2004) may also have directly or indirectly affected insect herbivore preference (Stout et al. 2006). In this study, only part of these possible effects could be studied in the field because of a low diversity in herbivore species composition (most of the insects found were aphids representing only one insect order and one feeding strategy) (II).

\section{Impact of the sugar beet chitinase IV transgene to leaf properties (III)}

Leaf properties differed between some chitinase transgenic lines and the corresponding control in the field study material (Table 3.). In some lines, the water content of the leaves was lower and/or the leaf length was shorter compared to the control trees. Water content was similarly higher in some transgenic lines compared to the control in the greenhouse study, but the leaves were shorter as in the field trial material. This possible influence of the growing environment on (unintentional) plant properties has to be taken into account in the risk management of GM trees (Snow et al. 2005). Until currently, unintentional plant properties e.g. altered leaf size and leaf area have only been studied with some crop plants. The results of Sun et al. (2013) showed unintentional effects on leaf area, whereas Jiang and Xiao (2010) found no clear effects on leaf size.

Table 3. Effect of the sugar beet chitinase IV on the studied traits (studies I-IV). + = increased, - = decreased, $0=$ no effect. Only statistically significant (except the total number of damage types) differences between the transgenic lines and the controls are presented.

\begin{tabular}{|c|c|c|c|c|}
\hline Plant material & $\begin{array}{l}\text { Growing } \\
\text { conditions }\end{array}$ & Plant trait & $\begin{array}{l}\text { Effect } \\
\text { positive (+) / } \\
\text { negative }(-) \text { / } \\
\text { no effect (0) }\end{array}$ & $\begin{array}{l}\text { Paper } \\
\text { number }\end{array}$ \\
\hline \multirow{7}{*}{$\begin{array}{l}\text { Silver birch } \\
\text { ( } B . \text { pendula) } \\
\text { carrying the sugar } \\
\text { beet chitinase IV } \\
\text { gene }\end{array}$} & Field & Tree growth & - & I \\
\hline & Field & Leaf colour & - & I \\
\hline & Field & $\begin{array}{l}\text { Growth response after } \\
\text { wounding }\end{array}$ & 0 & III \\
\hline & Field & $\begin{array}{l}\text { Number of leaf damage } \\
\text { types }\end{array}$ & - & 1 \\
\hline & Field & Leaf damage level & 0 & I \\
\hline & Field & $\begin{array}{l}\text { Leaf water content } \\
\text { Leaf length }\end{array}$ & $\begin{array}{l}- \\
-\end{array}$ & III \\
\hline & Greenhouse & $\begin{array}{l}\text { Leaf water content } \\
\text { Leaf length }\end{array}$ & $\begin{array}{l}+ \\
-\end{array}$ & III \\
\hline
\end{tabular}


The difference in growth and phenology -related traits between transgenic and nontransgenic control birch lines (I, III) may be explained by the elevated stress status of the trees (Pasonen et al. 2008). Many of the studied traits may be connected with each other because stress can be both a predecessor and a result of herbivory. The differing leaf colour (red) was assumed to indicate increased stress which can explain the smaller length and lower water proportion of the leaves. It is likely that leaf quality was lower in the transgenic lines for many insect herbivores representing many herbivore guilds. It is also possible that chemical and/or morphological properties (e.g. plant volatiles, secondary chemistry and toughness) of the leaves were different (as in Birch et al. 2002 and Yabor et al. 2010) which affected plant acceptance and preference by herbivores.

\subsection{The impact of transgenes on herbivory in the field and feeding trials}

The sugar beet chitinase IV transgene had varying impacts on insect herbivores (Table 4.). Aphid density was higher on the transgenic lines but negative on the diversity of guild composition and to performance of $O$. antiqua. In some of the chitinase transgenic lines, the herbivore damage type composition representing feeding guilds was less variable than in the control and wild type trees, though the composition was mostly linked to the genotype of the tree and not the transgene expression.

The wounding experiment suggested that the growth response of the transgenic trees did not differ from the corresponding control trees. The wounding treatment additionally had no impact on insect growth. However, larval survival on the wounded leaves of high chitinase IV expression trees was lower than on unwounded leaves. The lower consumption rates (amount of consumed leaf material, trend in ECD (efficiency of conversion of digested food) and ECI (efficiency of conversion of ingested food)) on wounded leaves may be linked to the change in $\mathrm{C} / \mathrm{N}$ balance of these leaves, because water content was not affected (Herms and Mattson, 1992). Depending on the change in $\mathrm{C} / \mathrm{N}$ balance, it may induce the production of $\mathrm{C}$ (terpenes, phenolics) or $\mathrm{N}$ (alkaloids, proteinase inhibitors) based defence products. However, the balance of defensive and nutritive factors in birch is more complicated than earlier believed (Haukioja 2003). Haukioja (2003) suggested that the defence against folivorous insects is founded on at least three interacting systems based on 1) jasmonic acid and salicylic acid - rapid, induced responses, 2) phenols - delayed induced defences and 3) an elusive category - evolutionary time scale. Though interaction may seem obvious in laboratory, it becomes more complicated in the field trials. However, these results cannot be directly compared with natural consumption because the wounding treatment does not fully reflect natural herbivory (Hjältén 2004). For example phytochemical and growth responses may differ in studies with trees and lepidopterans: the phenolic content has been higher in natural damage responses compared to artificial damage (Lehtilä and Boalt 2004).

The variable impacts of transgenic material on insect and mammal feeding choices (Table 4.) suggest that the transgenic tree impacts on herbivores are hard to predict. In fact, variation occurred between and within herbivore species. The variability between the transgenic lines was high in several cases, and sometimes only one line differed from the other lines and/or from the corresponding control. This makes interpretation difficult. Even more difficult is to predict, which difference is meaningful from viewpoint of risk analysis, because the degree of difference between a GM plant and a non-transgenic control plant is not defined in terms of values or variables in GM regulations (Hilbeck et al. 2011). To 
Table 4. Effects of transgenic plant material on the studied herbivores (studies I-IV).

$+=$ positive effect, $-=$ negative effect, $0=$ no effect. Only statistically significant (differences between transgenic trees and wild-type control trees are shown except for the total number of feeding guilds) effects are shown.

\begin{tabular}{|c|c|c|c|c|}
\hline Plant material & $\begin{array}{l}\text { Growing } \\
\text { conditions }\end{array}$ & $\begin{array}{l}\text { Studied herbivores / } \\
\text { traits }\end{array}$ & $\begin{array}{l}\text { Effect on herbivore } \\
\text { positive }(+) / \\
\text { negative }(-) / \text { no effect }(0)\end{array}$ & $\begin{array}{l}\text { Paper } \\
\text { number }\end{array}$ \\
\hline \multirow{10}{*}{$\begin{array}{l}\text { Silver birch } \\
\text { (B. pendula) } \\
\text { carrying the } \\
\text { sugar beet } \\
\text { chitinase IV } \\
\text { gene }\end{array}$} & Field & Insect fauna: & + & I \\
\hline & & Aphid density & - & \\
\hline & & Insect diversity (insect & - & \\
\hline & & orders) & - & \\
\hline & & $\begin{array}{l}\text { Insect feeding guild } \\
\text { diversity }\end{array}$ & & \\
\hline & Field & $\begin{array}{l}\text { Birch cambium fly } \\
\text { (Phytobia betulae) / } \\
\text { occurrence }\end{array}$ & $\begin{array}{l}0 \text { (- indirect effect } \\
\text { because of reduced } \\
\text { growth) }\end{array}$ & 1 \\
\hline & Field & $\begin{array}{l}\text { Rusty tussock moth } \\
\text { (Orgyia antiqua) / } \\
\text { feeding, growth, survival }\end{array}$ & $\begin{array}{l}\text { - especially on high } \\
\text { chitinase expression }\end{array}$ & III \\
\hline & Greenhouse & $\begin{array}{l}\text { Buff-tip (Phalera } \\
\text { bucephala) / } \\
\text { feeding, growth, survival }\end{array}$ & 0 & III \\
\hline & Greenhouse & $\begin{array}{l}\text { Roe deer (Capreolus } \\
\text { capreolus) / } \\
\text { Preference }\end{array}$ & 0 & IV \\
\hline & Field & $\begin{array}{l}\text { Mountain hare (Lepus } \\
\text { timidus) / } \\
\text { Preference }\end{array}$ & - only in one line & IV \\
\hline \multirow{2}{*}{$\begin{array}{l}\text { Aspen }(P . \\
\text { tremula) and } \\
\text { hybrid aspen } \\
\text { (Populus } \\
\text { tremula } \mathrm{x} \\
\text { tremuloides ) } \\
\text { carrying the } \\
\text { pine pinosylvin } \\
\text { synthase gene }\end{array}$} & Greenhouse & $\begin{array}{l}\text { Mountain hare (Lepus } \\
\text { timidus) on aspen / } \\
\text { preference }\end{array}$ & +-0 controversial results & IV \\
\hline & Greenhouse & $\begin{array}{l}\text { Mountain hare (Lepus } \\
\text { timidus) on hybrid } \\
\text { aspen / preference }\end{array}$ & +-0 controversial results & IV \\
\hline
\end{tabular}

solve this problem, a concept of "substantial equivalence" has been used (Millstone et al. 1999) to demonstrate that a GM plant is substantially equivalent to the non-transformed parent plant, based on basic measured compounds (Hilbeck et al. 2011). However, this has been highly contested in biosafety evaluations because of the narrow focus on the newly 
expressed protein (toxicity tests, see 1.1.) and not the whole plant (Birch et al. 2002; Hilbeck et al. 2011). The impacts observed in our studies seemed both direct (e.g. the chitinase effect on the gut) and indirect (e.g. effect of tree quality on herbivores). Some effects on herbivores were indirect as was the case with $P$. betulae. Aphids may also have indirectly benefited from the larger spectrum in leaf quality (higher variation in stress symptoms and phenology) that the other herbivore guilds may have not preferred.

Non-target effects of chitinase transgenic material on insect herbivores were found as seen in guild composition and the $O$. antiqua feeding trial. Results of the variation in feeding guild and damage type composition reveal the same result: a part of the chitinase transgenic lines was less suitable for more specialized insects such as leaf miners and leaf rollers. Some insect guilds or species living within leaves or leaf rolls, e.g. Byctiscus betulae L. and Eriocrania sparmannella Bosc, may not prefer chitinase transgenic trees. Some of the herbivores feeding on them may grow smaller and even suffer from higher mortality. Certain insect herbivores e.g. the leaf aphids may profit from the gene modification. This suggests the possibility that species composition (and further the food web) of birch can change as a result of the transgenic status of the trees. This changed herbivore pressure can be seen as an ecological adverse impact of the transgenic trees (see 1.1.). Changed species composition may lead to increased herbivore pressure because aphids and other sap-feeders may be more detrimental to the trees than folivores (Zvereva et al. 2010).

The positive response of leaf aphids to chitinase transgenic trees may be explained by the rapid and sensitive response among insect feeding guilds to plant stress (Larsson 1989; Holopainen 2011). They have shown positive performance on abiotically stressed forest trees (B. pendula, P. tremuloides) under $\mathrm{CO} 2$ and $\mathrm{O} 3$ treatments (Neuvonen and Lindgren 1987; Percy et al. 2002) despite the response to O3 being negative later on when feeding on B. pendula (Peltonen et al. 2010). The mechanism behind this rapid response of sap-feeders has been explained by the nutrient translocation theory in which a stressed plant translocates nutrients from older to younger parts providing free amino acids (Dohmen et al. 1984). This mechanism has been used to explain high numbers of aphids in yellow senescating leaves of $B$. pendula (Holopainen and Peltonen 2002). The quick reproductive response of aphids may contribute to this response (Larsson 1989). The response of aphids is probably also related to their nutrition physiology. Phloem sap is claimed to be generally free of toxins and feeding deterrents (Douglas 2006), but if transgenic chitinase was found in it, it could probably not wound the peritrophic matrix (in the midgut) because most Hemipterans such as aphids lack it (Hegedus et al. 2009). Positive and non-negative responses of aphids have been found in transgenic plants producing Bt-toxins (Faria et al. 2007; Himanen et al. 2008). Despite the possibility that aphids can ingest Bt toxin through phloem sap into their bodies (Burgio et al. 2011), the toxin does not seem to harm them, probably because of enzymatic and $\mathrm{pH}$ related properties in their gut (Chougule and Bonning 2012). The transgenic toxin may nevertheless be released from Bt-plants through aphids into non-target predators and the environment.

Growing conditions influence ecological interactions, and consequently the interactions between GM plants and other organisms. For example, complex interactions (abiotic and biotic) in the field may weaken the observed interactions between plants and other organisms as suggested by Halpin et al. (2007). This could partly explain the result that the chitinase transgenic lines showed increased resistance against the leaf spot pathogen (Pyrenopeziza betulicola Fuckel) in the greenhouse (Pappinen 2002), but reduced resistance in the field (Pasonen 2004) compared to the corresponding control trees. Signs of weaker 
in-field resistance compared to greenhouse conditions have also been found in other plants genetically modified against fungi (Stefani and Hamelin 2010). One explanation is that greenhouse and field studies screen different resistance types: resistance to inoculation and resistance to spreading (Anand et al. 2003). Pasonen et al. (2004) explained the reduced resistance by different $P$. betulicola genotypes in the field compared to the greenhouse. The over-expression of chitinase may also have a fitness cost on cell functions and plant defense. Stress caused by ecological interactions (e.g. insect herbivores) may also have explained the difference. The importance of field testing as a method to identify various pleiotropic effects of transgenic trees is essential in the early phases of research (Wei et al. 2006) for example because the effects may be cumulative (Brunner et al. 2007).

\section{The effects of the level of sugar beet chitinase IV expression}

The expression level of the of the sugar beet chitinase IV transgene did not clearly affect tree growth, leaf phenology, the feeding preferences of mammalian herbivores or the insect herbivore $P$. bucephala. Instead, it did influence the parameters related to the stress status of a tree and the performance of the insect herbivore $O$. antiqua. Stress per se has not previously been linked with GM plants/trees as a non-target effect, but plant stress has been considered an important factor explaining herbivory (Larsson 1989). The increased stress status of the trees in this study seems to have been beneficial to aphids. On the other hand, the increased aphid density on transgenic trees may have caused increased stress in the trees indicated by parameters reflecting general condition (see Zvereva et al. 2010) and leaf colour in trees expressing high levels of sugar beet chitinase IV. The negative impact of transgenic chitinase on the growth of $O$. antiqua may have resulted from the higher chitinase susceptibility of the insect. This could be explained by a higher proportion of chitin in the gut of $O$. antiqua that may be wounded by the transgenic chitinase, which could lead to e.g. their increased disease susceptibility (Tellam and Eisemann 2000; Hegedus et al. 2009). The response of $O$. antiqua may also have resulted from more diverse biotic interactions of trees with other organisms such as fungi and insects that could have lowered leaf quality in the field trial (the study with $O$. antiqua) trees compared to greenhouse grown trees (the study with $P$. bucephala).

\section{CONCLUSIONS}

The results gained especially from the tree growth studies of trees and the feeding studies of $O$. antiqua showed that particularly the studied transgene sugar beet chitinase IV had unintentional/non-target effects on herbivores and plant properties important to herbivores. The effects varied both within (L. timidus) and between the studied herbivores (insects vs. mammals, $O$. antiqua vs. $P$. bucephala). Indirect effects were revealed like growth and stress status that were mediated through tree properties.

The sugar beet chitinase IV transgene was found to lower tree vigour (lower growth and increased tree stress level) in the field trial, and reduced insect herbivore diversity induced changes in herbivore species composition and consequently resulted in changes in the relative degree of different leaf damage types. Leaf phenology was also affected, which in turn may affect insect herbivore survival and species composition. For example, transgenic 
trees had a positive effect on aphid density. Lower tree vigour and simplified herbivore diversity may reflect changes in leaf quality properties important to insect herbivores (changes were found in colour, length and water content) which should be studied in more detail. On the other hand, if only one leaf trait important to herbivory can be studied, foliar water should be chosen (Haukioja 2003). The difference in the composition of leaf damage types representing different feeding guilds may have resulted from both changed leaf quality and the different phenological window of the GM trees compared to control trees. Aphids may have benefited from increased stress levels of the trees, changed leaf quality or low interspecies competition.

The feeding trials revealed that the sugar beet chitinase IV transgene can negatively affect the growth of lepidopteran larvae especially when expressing at a high level. Since pathogen pressure was changed in the chitinase transgenic trees compared to the control, it may also have affected leaf-feeding insect herbivores directly through changes in appearance (e.g. leaf colour, leaf toughness/moisture) or indirectly via pathogen-induced changes in leaf nutritional quality ( $\mathrm{C}, \mathrm{N}$, defensive metabolites) e.g. through increased amounts of free amino acids in the leaf. Vice versa, insect herbivores may have provided entry sites for pathogens. The sugar beet chitinase IV transgene did not affect palatability to roe deer, but had a trend towards a negative effect on mountain hare feeding preference. It did not have a direct effect on $P$. betulae appearance, but indirect negative effect through lower tree growth. Pinosylvin synthase transgene had a variable effect on hare feeding preference. The variable effects between all the herbivore species may be connected to their different feeding preferences (and niches) although no single factor that was studied (sugar/starch proportion and leaf moisture) could be clearly connected thereto. The observed effects do not seem to be detrimental to any of the studied herbivores. The responses of insects to GM materials were stronger and more negative compared to the responses of the studied mammals. The differences between GM and control trees in insect species composition and herbivore preference suggest that the impact of one transgene may have broad impacts on tree-herbivore-interaction.

Transgenic trees targeted against fungal infections had variable non-target effects on the studied herbivores and tree growth and quality. The results revealed that GM trees can have non-target effects on plants and herbivores that can be explained either by pleiotropic effects of the transgene, epigenetic or environmental factors, or the genetic background of the GM trees. The constitutive expression of a transgenic chitinase gene may have disturbed the function of the silver birch's own chitinase genes, which could be seen as stress. Increased aphid density in some GM lines may also have added stress.

The variability in the results underlines the many needs in GM tree research. Firstly, the longevity of trees addresses the need for long-term studies concerning ecological interactions of transgenic trees. Secondly, the results suggest that GM studies should be conducted not only in the laboratory but also in field conditions to gain more valid information (in this case stronger effects) on more natural plant-herbivore interactions. Studies should be conducted on a case-by-case basis because of the complexity of ecological interactions in forest trees. Further, studies should not concentrate on transgene (and the toxicologic tests) per se, but should be based on its potential non-target effects on different ecological scales ranging from the species to the ecosystem level. This is important because the results of non-target studies are often different than expected, implying that researchers do not have sufficient understanding on the potential environmental impacts of GM plants. To improve the ERA of GM trees, research on factors affecting ecological interactions are highly needed. Transgenic material should also be 
generated on a broader genetic base, i.e. gene transfers should cover several genotypes of the recipient plant species instead of one or two, to reveal the "behaviour" of the transgene in variable genetic environments. Tri-trophic-interaction studies (host plant - herbivore natural enemy) addressing GM plants in a changing climate have not yet been performed with trees, but already with Bt crops (Chen et al. 2005; Himanen et al. 2008), resulting in positive or non-negative results with aphids. It is likely that GM trees would have even more complex interactions due to the important role of a tree's genotype in this tri-trophic interaction (Holton et al. 2003). Our results with aphids showed that parasitism level did not seem to differ between chitinase transgenic and control trees (L. Vihervuori, P. Lyytikäinen-Saarenmaa and H.-L. Pasonen unpublished data).

Because the impacts are variable, indirect and species/genotype-dependent, the total impacts of one transgene in a forest ecosystem are difficult to predict. Even ecologically very similar species may show different responses to GM material. Variable environmental conditions, even climate change, may affect this interaction. Netherer and Schopf (2010) argued that European forestry is likely to face diverse consequences of climate change ranging from altered incidence and intensity of pest outbreaks to changes in distributional ranges of insect herbivores. More specifically, higher winter temperatures may benefit pests by increasing survived hibernating eggs. Secondly, warm and dry spring and summer periods may lead to multiple insect generations. Higher storm frequency may also enhance pest development and abundance. Biotechnology may help forestry to meet these new requirements (Fenning et al. 2008). In this view, old forests could be left in as near a virgin state as possible, and plantations would be designed to maximize yield (Fenning et al. 2008). New engineering techniques may offer new possibilities for tree breeding by minimizing the disadvantageous pleiotropic effects of the transgene (Niskanen et al. 2011). Further, when discussing the commercial future of GM trees, the diversity of genetic background of GM material must be evaluated (Niskanen et al. 2011) (i.e. the number of clones into the gene transfer should be assessed). From the viewpoint of risk assessment (and of the desired novel trait) it is important that the transferred gene functions in a similar way in each receiving genotype.

The ERA conclusions on the interactions between GM trees and non-target herbivores (EFSA 2010a,b, 2001/18/EC and 2002/623/EC), including overall risk evaluation, were based on steps 1 to 5 of the step-by-step approach. The risk for adverse effects (step 6) was a) high for tree growth and quality, b) high for insect density and composition, c) moderate for leaf feeding lepidopterans, and d) low for mammalian herbivores. Uncertainties remain: limitations in the data, gaps in the effect database, uncertainties in extrapolating between species, and differing interpretations of the existing data. The findings of this study suggest that the current precautionary approach of Finland and the EU is justifiable and will be so until the uncertainties in ecological interactions have been decreased.

\section{REFERENCES}

van Acker R., Leplé J.-C., Aerts D., Storme V., Goeminne G., Ivens B., Légée F., Lapierre C., Piens K., Van Montagu M.C.E., Santoro N., Foster C.E., Ralph J., Soetaert W., Pilate G., Boerjan W. (2014). Improved saccharification and ethanol yield from fieldgrown transgenic poplar deficient in cinnamoyl-CoA reductase. PNAS 111: 845-850. 
http://dx.doi.org/10.1073/pnas.1321673111

Aguilera J., Nielsen K.M., Sweet J. (2013). Risk assessment of GM trees in the EU: Current regulatory framework and guidance. Iforest 6: 127-131.

http://dx.doi.org/10.3832/ifor0101-006

Ahuja M.R. (2011). Fate of transgenes in the forest tree genome. Tree Genetics \& Genomes 7: $221-230$.

http://dx.doi.org/10.1007/s11295-010-0339-1

Anand A., Zhou T., Trick H.N., Gill B.S., Bockus W.W., Muthukrishnan S. (2003).

Greenhouse and field testing of transgenic wheat plants stably expressing genes for thaumatin like protein, chitinase and glucanase against Fusarium graminearum. Journal of Experimental Botany 54: 1101-11.

http://dx.doi.org/10.1093/jxb/erg110

Andow D.A., Birch A.N.E., Dusi A.N., Fontes E.M.G., Hilbeck A., Lang A., Lövei, G.L., Pires C.S.S., Underwood E., Wheatley R.E. (2006). Non-target and Biodiversity Risk Assessment for Genetically Modified (GM) Crops. Proceedings - 9th International Symposium on the Biosafety of Genetically Modified Organisms (ISBR), pp. 68-73. http://www.gmoera.umn.edu/public/publications/download/Andowetal2006_ISBR.pdf

Andow D.A., Hilbeck A. (2004). Science-based risk assessment for nontarget effects of transgenic crops. BioScience 54: 637-649.

http://dx.doi.org/10.1641/0006-3568(2004)054[0637:SRAFNE]2.0.CO;2

Andow, D.A., Zwahlen, C. (2006). Assessing environmental risks of transgenic plants. Ecology Letters 9: 196-214. http://dx.doi.org/111/j.1461-0248.2005.00846.x

Annila E. (1987). Rauduskoivulla (Betula pendula) elävät hyönteiset. Sorbifolia 18: 118122. (in Finnish)

Archetti M., Döring T.F., Hagen S.B., Hughes N.M., Leather S.R., Lee D.W., Lev-Yadun S., Manetas Y., Ougham H.J., Schaberg P.G., Thomas H. (2009). Unravelling the evolution of autumn colours: an interdisciplinary approach. Trends in Ecology and Evolution 24: 166-173. http://dx.doi.org/10.1016/j.tree.2008.10.006

van Asch M., Visser M.E. (2007). Phenology of forest caterpillars and their host trees: The importance of synchrony. Annual Review of Entomology 52: 37-55. http://dx.doi.org/10.1146/annurev.ento.52.110405.091418

Arakane Y., Muthukrishnan S. (2010). Insect chitinase and chitinase-like proteins. Cellular and molecular life sciences 67: 201-216. http://dx.doi.org/10.1007/s00018-009-0161-9

Axelsson E.P., Hjältén J., LeRoy C.J., Whitham T.G., Julkunen-Tiitto R., Wennström A. (2011a). Leaf litter from insect-resistant transgenic trees causes changes in aquatic insect community composition. Journal of Applied Ecology 48: 1472-1479. http://dx.doi.org/10.1111/j.1365-2664.2011.02046.x

Axelsson E.P., Hjältén J., Thomas G., Whitham, Julkunen-Tiitto R., Pilate G., Wennstrom A. (2011b). Leaf ontogeny interacts with Bt modification to affect innate resistance in GM aspens. Chemoecology 21: 161-169.

http://dx.doi.org/10.1007/s00049-011-0080-8

Axelsson E.P., Hjältén J., LeRoy C.J. (2012). Performance of insect-resistant Bacillus thuringiensis $(\mathrm{Bt})$-expressing aspens under semi-natural field conditions including natural herbivory in Sweden. Forest Ecology and Management 264: 167-171. http://dx.doi.org/10.1016/j.foreco.2011.10.006 
Bautista N.S., Sagers C.L., Lee E.H., Watrud L.S. (2010). Flowering times in genetically modified Brassica hybrids in the absence of selection. Canadian Journal of Plant Science 90: 185-187. http://dx.doi.org/10.4141/CJPS09047

Bettini P., Michelotti S., Bindi D., Giannini R., Capuana M., Buiatti M. (2003). Pleiotropic effect of the insertion of the Agrobacterium rhizogenes rol D gene in tomato (Lycopersicon esculentum). Theoretical and Applied Genetics 107: 831-836. http://dx.doi.org/10.1007/s00122-003-1322-0

Birch A.N.E., Geoghegan I.E., Griffiths D.W., McNicol J.W. (2002). The effect of genetic transformations for pest resistance on foliar solanidine-based glycoalkaloids of potato (Solanum tuberosum). Annals of Applied Biology 140: 143-149. http://dx.doi.org/10.1111/j.1744-7348.2002.tb00166.x

Bolar J.P., Norelli J.L., Wong K.W., Hayes C.K., Harman G.E., Aldwinckle H.S. (2000). Expression of endochitinase from Trichoderma harzianum in transgenic apple increases resistance to apple scab and reduces vigor. Phytopathology 90: 72-7. http://dx.doi.org/10.1094/PHYTO.2000.90.1.72.

Brändle M., Brandl R. (2001). Species richness of insects and mites on trees: expanding Southwood. Journal of Animal Ecology 70: 491-504. http://dx.doi.org/10.1046/j.1365-2656.2001.00506.x

Brunner A.M., Li J., DiFazio S.P., Shevchenko O., Montgomery B.E., Mohamed R. Wei H., Ma C., Ani A.E., VanWormer K., Strauss S.H. (2007). Genetic containment of forest plantations. Tree Genetics \& Genomes 3: 75-100. http://dx.doi.org/10.1007/s11295-006-0067-8

Brunner A.M., Li J., DiFazio S.P., Shevchenko O., Montgomery B.E., Mohamed R., Wei H., Ma C., Elias A.A., VanWormer K., Strauss, S.H. (2010). Genetic containment of forest plantations. In: El-Kassaby, Y. (ed.). Forests and genetically modified trees. FAO, Rome, Italy, pp. 35-76. http://www.fao.org/docrep/013/i1699e/i1699e.pdf.

Bryant J.P., Stuart F., Chapin, F.S, Klein, D.R. (1983). Carbon/nutrient balance of boreal plants in relation to vertebrate herbivory. Oikos 40: 357-368.

Burgio G., Dinelli G., Marotti, I., Zurla M., Bosi S., Lanzoni A. (2011). Bt-toxin uptake by the non-target herbivore, Myzus persicae (Hemiptera: Aphididae), feeding on transgenic oilseed rape in laboratory conditions. Bulletin of Entomological Research 101: 241247. http://dx.doi.org/10.1017/S0007485310000441

Bussink A.P., Speijer D., Aerts J.M.F.G., Boot R.G. (2007). Evolution of Mammalian Chitinase(-Like) Members of Family 18 Glycosyl Hydrolases. Genetics 177: 959-970. http://dx.doi.org/10.1534/genetics.107.075846

Cao C-W, Liu G-F, Wang Z-Y, Yan S-C , Ma L., Yang C-P (2010): Response of the gypsy moth, Lymantria dispar to transgenic poplar, Populus simonii $\mathrm{x}$ P. nigra, expressing fusion protein gene of the spider insecticidal peptide and Bt-toxin C-peptide. Journal of Insect Science 10: 200. http://dx.doi.org/10.1673/031.010.20001

Cabinet bill 246/2009 (Finland), proposing the enactment of an Act on transgenic plant production (expired) (in Finnish) http://www.finlex.fi/fi/esitykset/he/2009/20090246

Campbell M.M., Brunner A.M., Jones H.M., Strauss S.H. (2003). Forestry's fertile crescent: the application of biotechnology to forest trees. Plant Biotechnology Journal 1: 
$141-154$.

http://dx.doi.org/10.1046/j.1467-7652.2003.00020.x

Convention of Biological diversity (2000). COP 6 Decision VI/6 The International Treaty on Plant Genetic Resources for Food and Agriculture.

http://www.cbd.int/decision/cop/?id=7180

Chen F., Ge F., Parajulee M.N. (2005). Impact of Elevated $\mathrm{CO}_{2}$ on Tri-Trophic Interaction of Gossypium hirsutum, Aphis gossypii, and Leis axyridis. Environmental Entomology 34: $37-46$.

http://dx.doi.org/10.1603/0046-225X-34.1.37

Chong J., Poutaraud A., Hugueney P. (2009). Metabolism and roles of stilbenes in plants. Plant Science 177: 143-155. http://dx.doi.org/10.1016/j.plantsci.2009.05.012

Chougule N.P., Bonning B.C. (2012). Toxins for transgenic resistance to hemipteran pests.Toxins (Basel) 4:405-29. http://dx.doi.org/10.3390/toxins4060405.

Christopher M.E., Miranda M., Major, I.T., Constabel C.P. (2004). Gene expression profiling of systemically wound-induced defenses in hybrid poplar. Planta 219: 936-947.

http://dx.doi.org/0.1007/s00425-004-1297-3

Clarke H.R.G., Lawrence S.D., Flaskerud J., Korhnak T.E., Gordon M.P., Davis J.M. (1998). Chitinase accumulates systemically in wounded poplar trees. Physiologia Plantarum 103: 154-161. http://dx.doi.org/10.1034/j.1399-3054.1998.1030202.x

Clausen T.P., Reichardt P.B., Bryant J.P. (1986). Pinosylvin and pinosylvin methyl ether as feeding deterrents in green alder. Journal of Chemical Ecology 12: 2117-2131. http://dx.doi.org/10.1007/BF01020314

Close D.C., Beadle, C.L. (2003). The ecophysiology of foliar anthocyanin. Botanical Review 69: 149-161. http://dx.doi.org/10.1663/0006-8101(2003)069[0149:TEOFA]2.0.CO;2

Collinge D.B., Kragh K.M., Mikkelsen J.D., Nielsen K.K., Rasmussen U., Vad K. (1993). Plant chitinases. Plant Journal 3: 31-40.

Conner A.J., Glare T.R., Nap J.-P. (2003). The release of genetically modified crops into the environment. Part II. Overview of ecological risk assessment. Plant Journal 33: 1946. http://dx.doi.org/10.1046/j.0960-7412.2002.001607.x

Corrado G., Arciello S., Fanti P., Fiandra L., Garonna A., Digilio M.C., Lorito M., Giordana B., Pennacchio F., Rao R. (2008). The Chitinase A from the baculovirus AcMNPV enhances resistance to both fungi and herbivorous pests in tobacco. Transgenic Research 17: 557-571. http://dx.doi.org/10.1007/s11248-007-9129-4

Dahiya N., Tewari R., Hoondal G.S. (2006). Biotechnological aspects of chitinolytic enzymes: a review. Applied Microbiology and Biotechnology 71: 773-782. http://dx.doi.org/10.1007/s00253-005-0183-7

Dandekar A.M., McGranahan G.H., Vail P.V., Uratsu S.L., Leslie C.A., Tebbets J.S. (1994). Low levels of expression of wild type Bacillus thuringiensis var. kurstaki; cry1A(c) sequences in transgenic walnut somatic embryos. Plant Science 96: 151-162.

Dearing M.D., Foley W.J., McLean S. (2006). The influence of plant secondary metabolites on the nutritional ecology of herbivorous terrestrial vertebrates. Annual Review of 
Ecology, Evolution, and Systematics 36: 169-189.

http://dx.doi.org/10.1146/annurev.ecolsys.36.102003.152617

Desneux N., Bernal J.S. (2010). Genetically modified crops deserve greater

ecotoxicological scrutiny. Ecotoxicology 19: 1642-4.

http://dx.doi.org/:10.1007/s10646-010-0550-8

Ding X., Gopalakrishnan B., Johnson L.B., White F.F., Wang X., Morgan T.D., Kramer K.J., Muthukrishnan S. (1998). Insect resistance of transgenic tobacco expressing an insect chitinase gene. Transgenic Research 7: 77-84.

http://dx.doi.org/10.1023/A:1008820507262

Dobbertin M. (2005). Tree growth as indicator of tree vitality and of tree reaction to environmental stress: a review. European Journal of Forest Research 124: 319-333. http://dx.doi.org/:10.1007/s10342-005-0085-3

Dohmen G.P., McNeill S., Bell J.N.B. (1984). Air-pollution increases Aphis fabae pest potential. Nature 307: 52-53.

http://dx.doi.org/:10.1038/307052a0

Doty L., James C.A., Moore A.L., Vajzovic A., Singleton G.L., Ma C., Khan Z., Xin G., Kang J.W., Park J.Y., Meilan R., Strauss S.H., Wilkerson J., Farin F., Strand S.E. (2007). Enhanced phytoremediation of volatile environmental pollutants with transgenic trees. Proceedings of the National Academy of Sciences of the United States of America 104: 16816-16821. http://dx.doi.org/10.1073/pnas.0703276104

Douglas A.E. (2006). Phloem-sap feeding by animals: problems and solutions. Journal of Experimental Botany 57: 747-754. http://dx.doi.org/10.1093/jxb/erj067

EFSA (2010a): Scientific opinion on the assessment of potential impacts of genetically modified plants on non-target organisms. EFSA Journal 8:1877. $72 \mathrm{pp}$. http://dx.doi.org/10.2903/j.efsa.2010.1877

EFSA (2010b): Guidance on the environmental risk assessment of genetically modified plants. EFSA Journal 8: 1879. 111 pp. http://dx.doi.org/10.2903/j.efsa.2010.1879.

Emani C., Garcia J.M., Lopata-Finch E., Pozo M.J., Uribe P., Kim D.-J., Sunilkumar G., Cook D.R., Kenerley C.M., Rathore K.S. (2003). Enhanced fungal resistance in transgenic cotton expressing an endochitinase gene from Trichoderma virens. Plant Biotechnology Journal 1: 321-336. http://dx.doi.org/10.1046/j.1467-7652.2003.00029.x

EC Decision 2002/623/EC: Establishing guidance notes supplementing Annex II to Directive 2001/18/EC of the European Parliament and of the Council on the deliberate release into the environment of genetically modified organisms and repealing Council Directive 90/220/EEC.

http://eurlex.europa.eu/LexUriServ/LexUriServ.do?uri=OJ:L:2002:200:0022:0033:EN:PDF

EU Directive 2001/18/EC: On the deliberate release into the environment of genetically modified organisms. http://eur-lex.europa.eu/legal-content/EN/TXT/?uri=CELEX:32001L0018

EU Directive 2009/41/EC: On the contained use of genetically modified micro-organisms. http://eur-lex.europa.eu/legal-content/EN/TXT/?uri=CELEX:32009L0041

FAO 2004. Preliminary review of biotechnology in forestry, including genetic modification. Working Paper FGR/59E. 
http://www.fao.org/3/a-ae574e.pdf

Faria C.A., Wäckers F.L., Pritchard J., Barrett D.A., Turlings T.C. (2007). High

Susceptibility of Bt Maize to Aphids Enhances the Performance of Parasitoids of

Lepidopteran Pests. PLOS ONE 2(7): e600.

http://dx.doi.org/10.1371/journal.pone.0000600

Feeny P. (1970). Seasonal changes in oak leaf tannins and nutrients as a cause of spring feeding by winter moth caterpillars. Ecology 51: 565-581.

http://dx.doi.org/http://dx.doi.org/10.2307/1934037

Fenning T.M, Walter C., Gartland K.M.A. (2008). Forest biotech and climate change.

Nature Biotechnology 26: 615-617.

http://dx.doi.org/10.1038/nbt0608-615

Fiandra L., Terracciano I., Fanti P., Garonna A., Ferracane L., Fogliano V., Casartelli M., Giordana B., Rao R., Pennacchio F. (2010). A viral chitinase enhances oral activity of TMOF. Insect Biochemistry and Molecular Biology 40: 533-540.

http://dx.doi.org/10.1016/j.ibmb.2010.05.001

Fillatti J.J., Sellmer J., McCown B., Haissig B., Comai L. (1987). Agrobacterium mediated transformation and regeneration of Populus. Molecular Genetics and Genomics 206: 192-199.

http://dx.doi.org/10.1007/BF00333574

Fladung M. (1999). Gene stability in transgenic aspen-Populus. I. Flanking DNA sequences and T-DNA structure. Molecular Genetics and Genomics 260: 574-581. http://dx.doi.org/10.1007/s004380050931

Fladung M., Pasonen H.-L., Walters C. (2010). Genetically modified trees and environmental concerns. In: El-Kassaby, Y. (ed.) Forests and Genetically Modified Trees. FAO, Rome, pp. 177-201. http://www.fao.org/docrep/013/i1699e/i1699e.pdf

Fladung M., Hoenicka H, Ahuja, M.R. (2013). Genomic stability and long-term transgene expression in poplar. Transgenic Research_22: 1167-78. http://dx.doi.org/10.1007/s11248-013-9719-2.

Foster J.R., Townsend P.A., Mladenoff D.J. (2013). Mapping asynchrony between gypsy moth egg-hatch and forest leaf-out: Putting the phenological window hypothesis in a spatial context. Forest Ecology and Management 287: 67-76. http://dx.doi.org/10.1016/j.foreco.2012.09.006

van Frankenhuyzen K., Beardmore, T. (2004). Current status and environmental impact of transgenic forest trees. Canadian Journal of Forest Research 34: 1163-1180. http://dx.doi.org/10.1139/x04-024

Gao B.-J., Gao S.-H., Liu J.-X., Jiang W.-H. (2006). Variation of nutritional structure and ecological niche of arthropod community in plantation of transgenic insect-resistance hybrid poplar 741. Acta Ecologica Sinica 26: 3499-3507. (In Chinese with English abstract.)

Gatehouse A.M.R, Gatehouse J.A. (1998): Identifying proteins with insecticidal activity: use of encoding genes to produce insect-resistant transgenic crops. Pesticide Science 521: $165-175$. http://dx.doi.org/10.1002/(SICI)1096-9063(199802)52:2

Gatehouse A.M.R., Down R.E., Powell K.S., Sauvion N., Rahbé Y., Newell C.A., Merryweather A., Hamilton W.D.O., Gatehouse, J.A. (1996). Transgenic potato plants with enhanced resistance to the peach-potato aphid Myzus persicae. Entomologia Experimentalis et Applicata 79: 295-307. 
http://dx.doi.org/10.1111/j.1570-7458.1996.tb00837.x

Gatehouse A.M.R., Davison, G.M., Newell C.A., Merryweather, A., Hamilton W.D.O., Burgess E.P.J., Gilbert R.J.C., Gatehouse J.A. (1997). Transgenic potato plants with enhanced resistance to the tomato moth, Lacanobia oleracea: growth room trials. Molecular Breeding 3: 49-63. http://dx.doi.org/10.1023/A:1009600321838

Gatehouse A.M.R., Ferry N., Edwards M.G., Bell H.A. (2011): Insect-resistant biotech crops and their impacts on beneficial arthropods. Philosophical Transactions of the Royal Society Lond B: Biological Sciences 366: 1438-1452. http://dx.doi.org/10.1098/rstb.2010.0330

Geenitekniikkalaki 377/1995 (In Finnish) https://www.finlex.fi/fi/laki/ajantasa/1995/19950377

Gutiérrez-Campos R., Torres-Acosta J.A., Perez-Martínez J.J. (2001). Pleiotropic effects in transgenic tobacco plants expressing theoryzacystatin I gene. HortScience 36: 118-119.

Häggman H., Raybould A., Borem A., Fox T., Handley L., Hertzberg M., Lu M-Z, Macdonald P., Oguchi T., Pasquali G., Pearson L., Peter G., Quemada H., Seguin A., Tattersall K., Ulian E., Walter C., McLean, M. (2013). Genetically engineered trees for plantation forests: key considerations for environmental risk assessment. Plant Biotechnology Journal 11: 785-798. http://dx.doi.org/10.1111/pbi.12100

Halpin C., Thain, S.C., Tilston E.L., Guiney E., Lapierre C., Hopkins, D.W. (2007). Ecological impacts of trees with modified lignin. Tree Genetics \& Genomes 3: 101110. http://dx.doi.org/10.1007/s11295-006-0060-2

Hammerbacher A., Ralph S.G., Bohlmann J., Fenning T.M., Gershenzon J., Schmidt A. (2011). Biosynthesis of the major tetrahydroxystilbenes in spruce, astringin and isorhapontin, proceeds via resveratrol and is enhanced by fungal infection. Plant Physiology 157: 876-890. http://dx.doi.org/10./pp.1111104.181420

Hanhineva K., Kokko H., Siljanen H., Rogachev I., Aharoni A., Kärenlampi S.O. (2009). Stilbene synthase gene transfer caused alterations in the phenylpropanoid metabolism of transgenic strawberry (Fragaria $\times$ ananassa). Journal of experimental Botany 60: 2093-2106. http://dx.doi.org/10.1093/jxb/erp085

Hansen J., Møller I. (1975). Percolation of starch and soluble carbohydrates from plant tissue for quantitative determination with anthrone. Analytical Biochemistry 68: 87-94. http://dx.doi.org/10.1016/0003-2697(75)90682-X

Harcourt, R.L., Kyozuka J., Floyd R.B., Bateman K.S., Tanaka H., Decroocq V., Llewellyn D.J., Zhu X., Peacock W.J., Dennis E.S. (2000). Insect- and herbicide-resistant transgenic eucalypts. Molecular Breeding 6: 307-315. http://dx.doi.org/10.1023/A:1009676214328

Hart J.H. (1981). Role of phytostilbenes in decay and disease resistance. Annual Review of Phytopathology 19: 437-458.

http://dx.doi.org/10.1146/annurev.py.19.090181.002253

Haslberger A.G. (2003). Codex guidelines for GM foods include the analysis of unintended effects. Nature Biotechnology 21: 739-741.

http://dx.doi.org/10.1038/nbt0703-739

Haukioja E. (1990). Induction of Defenses in Trees. Annual Review of Entomology 36: 


\section{$25-42$.}

http://dx.doi.org/10.1146/annurev.en.36.010191.000325

Haukioja E. (2003). Putting the insect into the birch-insect interaction. Oecologia 136: 161168. http://dx.doi.org/10.1007/s00442-003-1238-z

Hegedus D., Erlandson M., Gillott C., Toprak U. (2009). New Insights into Peritrophic Matrix Synthesis, Architecture, and Function. Annual Review of Entomology 54: 285302. http://dx.doi.org/10.1146/annurev.ento.54.110807.090559

Herms D.A., Mattson W.J. (1992). The dilemma of plants: to grow or defend. Quarterly Review of Biology 67: 283-335. http://www.jstor.org/stable/2830650

Hilbeck A, Meier M., Römbke J., Jänsch S., Teichmann H., Tappeser B. (2011). Environmental risk assessment of genetically modified plants - concepts and controversies. Environmental Sciences Europe 23: 13. http://dx.doi.org/10.1186/2190-4715-23-13

Hilbeck A., Binimelis R., Defarge N., Steinbrecher R., Székács A., Wickson F., Antoniou M., Bereano P.L., Clark E.A., Hansen M., Novotny E., Heinemann J., Meyer H., Shiva V., Wynne B. (2015). No scientific consensus on GMO safety. Environmental Sciences Europe 27: 4. http://dx.doi.org/10.1186/s12302-014-0034-1

Himanen S.J., Nissinen A., Dong W.-X., Nerg A.-M., Stewart C.N., Poppy G.M., Holopainen J.K. (2008). Interactions of elevated carbon dioxide and temperature with aphid feeding on transgenic oilseed rape: are Bacillus thuringiensis $(\mathrm{Bt})$ plants more susceptible to nontarget herbivores in future climate? Global Change Biology 14: 14371454. http://dx.doi.org/10.1111/j.1365-2486.2008.01574.x

Hjältén J. (2004). Simulating herbivory: problems and possibilities. In: Weisser W.W. and Siemann E. (Eds.), Insects and ecosystem function, Springer-Verlag, Berlin, Germany, pp. 243-255.

http://dx.doi.org/10.1007/978-3-540-74004-9_12

Hjältén J., Lindau A., Wennström A., Blomberg P., Witzell J., Hurry V., Ericson L. (2007). Unintentional changes of defence traits in GM trees can influence plant-herbivore interactions. Basic and Applied Ecology 8: 434-443. http://dx.doi.org/10.1016/j.baae.2006.09.001

Hjältén J., Lindau A., Wennström A., Blomberg P., Witzell J., Hurry V., Ericson L., Moritz T., Karlsson J. (2008). Vole response to unintentional changes in the chemistry of GM poplars. Chemoecology 18: 227-231. http://dx.doi.org/10.1007/s00049-008-0409-0

Hjältén J, Axelsson E.P., Julkunen-Tiitto R., Wennström A., Pilate G. (2013). Innate and introduced resistance traits in genetically modified aspen trees and their effect on leaf beetle feeding. PLoS ONE 8(9): e73819. http://dx.doi.org/10.1371/journal.pone.0073819

Hoch W.A., Zeldin E.L., McCown B.H. (2001). Physiological significance of anthocyanins during autumn leaf senescence. Tree Physiology 21: 1-8. http://dx.doi.org/10.1093/treephys/21.1.1

Hoenicka H., Fladung M. (2006). Biosafety in Populus spp. and other forest trees: from non-native species to taxa derived from traditional breeding and genetic engineering. 
Trees - Structure and Function 20: 131-144.

http://dx.doi.org/10.1007/s00468-005-0023-5

Holopainen J. (2011). Can forest trees compensate for stress-generated growth losses by induced production of volatile compounds? Tree Physiology 31: 1356-1377. http://dx.doi.org/10.1093/treephys/tpr111

Holopainen J.K., Semiz G., Blande J.D. (2009). Life-history strategies affect aphid preference for yellowing leaves. Biology Letters 5: 603-605. http://dx.doi.org/10.1098/rsbl.2009.0372

Holopainen J.K., Peltonen P. (2002). Bright autumn colours of deciduous trees attract aphids: nutrient retranslocation hypothesis. Oikos 99: 184-188. http://www.jstor.org/stable/3547764

Holton M.K., Lindroth R.L., Nordheim E.V. (2003). Foliar quality influences treeherbivore-parasitoid interactions: effects of elevate $\mathrm{CO} 2, \mathrm{O} 3$, and plant genotype. Oecologia 137: 233-244. http://dx.doi.org/10.1007/s00442-003-1351-z

Howe G. A., Jander G. (2008). Plant Immunity to Insect Herbivores. Annual Review of Plant Biology 59: 41-66. http://dx.doi.org/10.1146/annurev.arplant.59.032607.092825

Hu J., Yang, M., Lu, M. (2010). Advances in biosafety studies on transgenic insectresistant poplars in China. Biodiversity Science 18: 336-345. (in Chinese with English abstract)

Huttunen L., Niemelä P., Julkunen-Tiitto R., Heiska S., Tegelberg R., Rousi M., Kellomäki S. (2008). Does defoliation induce chemical and morphological defenses in the leaves of silver birch seedlings under changing climate? Chemoecology 18: 85-98. http://dx.doi.org/10.1007/s00049-007-0397-5

Iason G. (2005). The role of plant secondary metabolites in mammalian herbivory: ecological perspectives. Proceedings of the Nutrition Society 64: 123-131. http://dx.doi.org/10.1079/PNS2004415

Jiang X., Xiao G. (2010). Detection of unintended effects in genetically modified herbicide-tolerant (GMHT) rice in comparison with non-target phenotypic characteristics. African Journal of Agricultural Research 5: 1082-1088.

Johnson S.N., Douglas A.E.,Woodward S., Hartley S.E. (2003). Microbial impacts on plant-herbivore interactions: the indirect effects of a birch pathogen on a birch aphid. Oecologia 134: 388-396. http://dx.doi.org/10.1007/s00442-002-1139-6

Jouanin, L., Bonadé-Bottino, M., Girard, C., Morrot, G., Giband, M. (1998). Transgenic plants for insect resistance. Plant Science 131: 1-11. http://dx.doi.org/10.1016/S0168-9452(97)00239-2

Jouanin L., Goujon T., de Nadai V., Martin M.T., Mila I., Vallet C., Pollet B., Yoshinaga A., Chabbert B., Petit-Conil M., Lapierre C. (2000). Lignification in transgenic poplars with extremely reduced caffeic acid O-methyltransferase activity. Plant Physiology 123: 1363-1373.

http://dx.doi.org/10.1104/pp.123.4.1363

Käppeli O., Auberson L. (1998). How safe is safe enough in plant genetic engineering? Trends in Plant Science 3: 276-281. http://dx.doi.org/10.1016/S1360-1385(98)01251-5

Karageorgou P., Buschmann' C., Manetas Y. (2008). Red leaf color as a warning signal against insect herbivory: honest or mimetic? Flora - Morphology, Distribution, 
Functional Ecology of Plants 203: 648-652.

http://dx.doi.org/10.1016/j.flora.2007.10.006

Kasprzewska A. (2003). Plant chitinases - regulation and function. Cellular \& Molecular Biology Letters 8: 809-824.

Klocko A.L., Meilan R., James R.R.,Viswanath V., Ma C., Payne P., Miller L., Skinner

J.S., Oppert B., Cardineau G.A., Strauss S.H. (2014). Bt-Cry3Aa transgene expression reduces insect damage and improves growth in field-grown hybrid poplar. Canadian Journal of Forest Research 44: 28-35.

http://dx.doi.org/10.1139/cjfr-2013-0270

Kramer K.J., Muthukrishnan S. (1997). Insect chitinases: Molecular biology and potential use as biopesticides. Insect Biochemistry and Molecular Biology 27: 887-900. http://dx.doi.org/10.1016/S0965-1748(97)00078-7

Kullberg Y., Bergström R. (2001). Winter browsing by large herbivores on planted deciduous seedlings in Southern Sweden. Scandinavian Journal of Forest Research 16: 371-378. http://dx.doi.org/10.1080/02827580117385

Kulman H.M. (1971). Effects of insect defoliation on growth and mortality of trees. Annual Review of Entomology 16: 289-324. http://dx.doi.org/10.1146/annurev.en.16.010171.001445

Kumar S., Fladung M. (2001). Gene stability in transgenic aspen (Populus). II. Molecular characterization of variable expression of transgene in wild and hybrid aspen. Planta 213: 731-40. http://dx.doi.org/10.1007/s004250100535

Kumar S., Fladung M. (2002). Transgene integration in aspen: structures of integration sites and mechanism of T-DNA integration. The Plant Journal: For Cell and Molecular Biology: 31: 543-51. http://dx.doi.org/10.1046/j.1365-313X.2002.01368.x

Lachance D., Hamel L.-P., Pelletier F., Valéro J., Bernier-Cardou M.,Chapman K., van Frankenhuyzen K., Séguin A. (2007). Expression of a Bacillus thuringiensis cry1 Ab gene in transgenic white spruce and its efficacy against the spruce budworm (Choristoneura fumiferana). Tree Genetics \& Genomes 3: 153-167. http://dx.doi.org/10.1007/s11295-006-0072-y

Laitinen J., Rousi M., Tahvanainen J. (2002). Growth and hare, Lepus timidus, resistance of white birch, Betula pendula, clones grown in different soil types. Oikos 99: 37-46. http://dx.doi.org/10.1034/j.1600-0706.2002.990104.x

Lappalainen J., Helander M.L., Palokangas P. (1995).The performance of the autumnal moth is lower on trees infected by birch rust. Mycological Research 99: 994-996. http://dx.doi.org/10.1016/S0953-7562(09)80763-6

Larsson S. (1989). Stressful times for the plant stress: Insect performance hypothesis. Oikos 56: 277-283. http://www.jstor.org/stable/3565348

Lawrence S.D., Novak N.G. (2006). Expression of poplar chitinase in tomato leads to inhibition of development in Colorado potato beetle. Biotechnology Letters 28: 593599. http://dx.doi.org/10.1007/s10529-006-0022-7

Lehtilä K., Boalt E. (2004). The Use and Usefulness of Artificial Herbivory in PlantHerbivore Studies. In: Weisser W.W. and Siemann E. (Eds.), Insects and ecosystem function, Springer-Verlag, Berlin, Germany, pp. 257-275. 
http://dx.doi.org/10.1007/978-3-540-74004-9_13

Lida W., Yifan H., Jianjun H. (2003). Transgenic forest trees for insect resistance. In: Kumar S., Fladung M. (Eds.). Molecular Genetics and Breeding of forest trees. The Haworth Press, Binghamton, USA, pp. 243-261.

Lin S.-Z., Zhang Z.-Y., Zhang Q., Lin Y.-Z. (2006). Progress in the study of molecular genetic improvements of poplar in China. Acta Botanica Sinica 48: 1001-1007. http://dx.doi.org/10.1111/j.1744-7909.2006.00303.x

Liu B., Zeng Q., Yan F., Xu H., Xu C. (2005). Effects of transgenic plants on soil microorganisms. Plant and Soil 271: 1-13. http://dx.doi.org/10.1007/s11104-004-1610-8

Lohtander K, Pasonen H-L, Palva T, Pappinen A, Rikkinen J. (2008). Phylogeny of chitinases and implications for estimating horizontal gene transfer from chitinase transgenic silver birch (Betula pendula). Environmental Biosafety Research 7: 227-239. http://dx.doi.org/10.1051/ebr:2008019

Löwei G.L., Andow D.A., Arpaia S. (2009). Transgenic insecticidal crops and natural enemies: a detailed review of laboratory studies. Environmental Entomology 38: 293-306.

Lu Y., Wu K., Jiang Y., Xia B., Li P., Feng H., Wyckhuys K.A.G., Guo Y. (2010). Mirid bug outbreaks in multiple crops correlated with wide-scale adoption of Bt cotton in China. Science 328: 1151-1154. http://dx.doi.org/10.1126/science.1187881

Lyytikäinen-Saarenmaa P., Tomppo E. (2002). Impact of sawfly defoliation on growth of Scots pine Pinus sylvestris (Pinaceae) and associated economic losses. Bulletin of Entomological Research 92:137-140. http://dx.doi.org/10.1079/BER2002154

Lännenpää M, Hassinen M., Ranki A., Hölttä-Vuori M, Lemmetyinen J., Keinonen K., Sopanen T. (2005). Prevention of flower development in birch and other plants using a BpFULL1::BARNASE construct. Plant Cell Reports 24: 69-78. http://dx.doi.org/10.1007/s00299-004-0903-y http://dx.doi.org/10.1603/022.038.0201

McNee W.R., Bonello P., Storer A.J., Wood D.L., Gordon T.R. (2003). Feeding response of Ips paraconfusus to phloem and phloem metabolites of Heterobasidion annosuminoculated Ponderosa pine, Pinus ponderosa. Journal of Chemical Ecology 29: 11831202. http://dx.doi.org/10.1023/A:1023885724220

Merkle S.A., Andrade G.M., Nairn C.J., Powell W.A., Maynard C.A. (2007). Restoration of threatened species: a noble cause for transgenic trees. Tree Genetics and Genomes 3: 111-118. http://dx.doi.org/10.1007/s11295-006-0050-4

Millstone E., Brunner E., Mayer S. (1999). Beyond 'substantial equivalence'. Nature 401: 525-526. http://dx.doi.org/10.1038/44006

Mouttet R., Bearez P., Thomas C., Desneux N. (2011). Phytophagous Arthropods and a Pathogen Sharing a Host Plant: Evidence for Indirect Plant-Mediated Interactions. PLoS One. 6(5): e18840. http://dx.doi.org/10.1371/journal.pone.0018840

Mutikainen P, Walls M., Ovaska J., Keinänen M., Julkunen-Tiitto R., Vapaavuori E. (2000). Herbivore resistance in Betula pendula: Effect of fertilization, defoliation, and 
plant genotype. Ecology 81: 49-65.

http://dx.doi.org/10.1890/0012-9658(2000)081[0049:HRIBPE]2.0.CO;2

Myhr A.I., Traavik T. (2002). The precautionary principle: scientific uncertainty and omitted research in the context of GMO use and release. Journal of Agricultural and Environmental Ethics 15: 73-86. http://dx.doi.org/10.1023/A:1013814108502

Myking T., BØhler F., Austrheim G., Solberg E.J. (2011). Life history strategies of aspen (Populus tremula L.) and browsing effects: a literature review. Forestry 84: 61-71. http://dx.doi.org/10.1093/forestry/cpq044

Netherer S., Schopf. A. (2010). Potential effects of climate change on insect herbivores in European forests - General aspects and the pine processionary moth as specific example. Forest Ecology and Management 259: 831-838.

http://dx.doi.org/10.1016/j.foreco.2009.07.034

Neuvonen S., Lindgren M. (1987). The effect of simulated acid-rain on performance of the aphid Euceraphis betulae (Koch) on silver birch. Oecologia 74: 77-80. http://dx.doi.org/10.1007/BF00377348

Niskanen A.-M., Kärkkäinen K., Pasonen H. (2011). Comparison of variation in adaptive traits between wild-type and transgenic silver birch (Betula pendula) in a field trial. Tree Genetics \& Genomes 7: 955-967. http://dx.doi.org/10.1007/s11295-011-0387-1

Nykänen H., Koricheva J. (2004). Damage-induced changes in woody plants and their effects on insect herbivore performance: a meta-analysis. Oikos 104: 247-268. http://dx.doi.org/10.1111/j.0030-1299.2004.12768.x

O’Callaghan M., Glare T.R., Burgess E.P.J., Malone, L.A. (2005). Effects of plants genetically modified for insect resistance on nontarget organisms. Annual Review of Entomology 50: 271-92. http://dx.doi.org/10.1146/annurev.ento.50.071803.130352

Pappinen A., Degefu Y., Syrjälä L., Keinonen K., von Weissenberg K. (2002). Transgenic silver birch (Betula pendula) expressing sugarbeet chitinase 4 shows enhanced resistance to Pyrenopeziza betulicola. Plant Cell Reports 20: 1046-1051. http://dx.doi.org/10.1007/s00299-002-0449-9

Pasonen H.-L., Seppänen S.-K., Degefu Y., Rytkönen A., von Weissenberg K. Pappinen A. (2004). Field performance of chitinase transgenic silver birches (Betula pendula): resistance to fungal diseases. Theoretical and Applied Genetics 109: 562-570. http://dx.doi.org/10.1007/s00122-004-1650-8

Pasonen H.-L., Degefu Y., Brumós J., Lohtander K., Pappinen A., Timonen S., Seppänen S.-K. (2005). Transgenic Betula pendula expressing sugar beet chitinase IV forms normal ectomycorrhizae with Paxillus involutus in vitro. Scandinavian Journal of Forest Research 20: 385-392. http://dx.doi.org/10.1080/02827580500251432

Pasonen H.-L., Lu J., Niskanen A.-M., Seppänen S.K., Rytkönen A., Raunio J., Pappinen A., Kasanen R., Timonen S. (2009). Effects of sugar beet chitinase IV on rootassociated fungal community of transgenic silver birch in a field trial. Planta 230: 973983.

http://dx.doi.org/10.1007/s00425-009-1005-4

Peeters P.J. (2002). Correlations between leaf structural traits and the densities of herbivorous insect guilds. Biological Journal of the Linnean Society 77: 43-65.

Peeters P.J., Read J., Sanson G.D. (2001). Variation in the guild composition of 
herbivorous insect assemblages among co-occurring plant species. Austral Ecology 26: 385-399.

http://dx.doi.org/10.1046/j.1442-9993.2001.01123.x http://dx.doi.org/10.1046/j.1095-8312.2002.00091.x

Peltonen P.A., Vapaavuori E., Heinonen J., Julkunen-Tiitto R., Holopainen J.K (2010). Do elevated atmospheric $\mathrm{CO} 2$ and $\mathrm{O} 3$ affect food quality and performance of folivorous insects on silver birch? Global Change Biology 16: 918-935. http://dx.doi.org/10.1111/j.1365-2486.2009.02073.x

Peña L., Séguin A. (2001). Recent advances in genetic transformation of trees. Trends in Biotechnology 19: 500-506. http://dx.doi.org/10.1016/S0167-7799(01)01815-7

Percy K.E., Awmack C.S, Lindroth R.L., Kubiske M.E., Kopper B.J., Isebrands J.G., Pregitzer K.S., Hendrey G.R., Dickson R.E., Zak D.R., Oksanen E., Sober J., Harrington R., Karnosky D.F. (2002). Altered performance of forest pests under atmospheres enriched by $\mathrm{CO}_{2}$ and $\mathrm{O}_{3}$. Nature 420: 403-407. http://dx.doi.org/10.1038/nature01028

Peterson J.A., Lundgren J.G., Harwood J.D. (2011). Interactions of transgenic Bacillus thuringiensis insecticidal crops with spiders (Araneae). The Journal of Arachnology 39: $1-21$. http://dx.doi.org/http://dx.doi.org/10.1636/M10-98.1

Pilate G., Guiney E., Petit-Conil M., Lapierre C., Leple J.-C., Pollet B., Mila I., Webster E.A., Marstrop H.G., Hopkins D.W., Jouanin L., Boerjan W., Schuch W., Cornu D., Halpin C. (2002). Field and pulping performances of transgenic trees with altered lignification. Nature Biotechnology 20: 607-612.

http://dx.doi.org/10.1038/nbt0602-607

Poppy G. (2000). GM crops: environmental risks and non-target effects. Trends in Plant Science 5: 4-6. http://dx.doi.org/10.1016/S1360-1385(99)01514-9

Post K.H., Parry D. (2011). Non-target effects of transgenic blight-resistant american chestnut (Fagales: Fagaceae) on insect herbivores. Environmental Entomology 40: 955963. http://dx.doi.org/10.1603/EN10063

Poupin M.J., Arce-Johnson P. (2005). Transgenic trees for a new era. In Vitro Cellular \& Developmental Biology. Plant 41: 91-101. http://dx.doi.org/10.1079/IVP2004587

Prittinen K., Pusenius J., Koivunoro K., Rousi M., Roininen H. (2003). Mortality in seedling populations of silver birch: genotypic variation and herbivore effects. Functional Ecology 17: 658-663. http://dx.doi.org/10.1046/j.1365-2435.2003.00777.x

Quilis J., Meynard D., Vila L., Avilés F. X., Guiderdoni E., San Segundo B. (2007). A potato carboxypeptidase inhibitor gene provides pathogen resistance in transgenic rice. Plant Biotechnology Journal 5: 537-553. http://dx.doi.org/10.1111/j.1467-7652.2007.00264.x

Rao R., Fiandra L., Giordana B., de Eguileor M., Congiu T., Burlini N., Arciello S., Corrado G., Pennacchio F. (2004). AcMNPV ChiA protein disrupts the peritrophic membrane and alters midgut physiology of Bombyx mori larvae. Insect Biochemistry and Molecular Biology 34: 1205-1213. http://dx.doi.org/10.1016/j.ibmb.2004.08.002 
Reuter H., Middelhoff U., Graef F., Verhoeven R., Batz T., Weis M., Schmidt G., Schröder W., Breckling B. (2010). Information system for monitoring environmental impacts of genetically modified organisms. Environmental Science and Pollution Research International 17: 1479-1490. http://dx.doi.org/10.1007/s11356-010-0334-y

Robischon N. (2006). Field Trials with Transgenic Trees - State of the Art and Developments. In: M. Fladung \& D. Ewald (Eds.) Tree Transgenesis: Recent Developments. Springer-Verlag Berlin and Heidelberg, Germany, pp. 3-23 http://dx.doi.org/10.1007/3-540-32199-3_1

Rostás M., Simon M.,Hilker M. (2003). Ecological cross-effects of induced plant responses towards herbivores and phytopathogenic fungi. Basic and Applied Ecology 4: 43-62. http://dx.doi.org/10.1078/1439-1791-00132

Russell G.B., Bowers W.S., Keesing V., Niemeyer H.M., Sevenet T., Vasanthaverni S., Wratten S.D. (2000). Patterns of bioactivity and herbivory on Nothofagus species from Chile and New Zealand. Journal of Chemical Ecology 26: 41-56. http://dx.doi.org/10.1023/A:1005433326418

Saalas U. (1949). Suomen metsähyönteiset sekä muut metsälle vahingolliset ja hyödylliset eläimet. WSOY, Porvoo. 719 pp. (In Finnish)

Saguez J., Hainez R., Cherqui A., Wuytswinkel O. Van, Jeanpierre H., Lebon G., Noiraud N., Beaujean A., Jouanin L., Laberche J.-C. (2005). Unexpected effects of chitinases on the peach-potato aphid (Myzus persicae Sulzer) when delivered via transgenic potato plants (Solanum tuberosum Linné) and in vitro. Transgenic Research 14: 57-67. http://dx.doi.org/10.1007/s11248-004-3100-4

Salwasser H. (2004). Future forests: Environmental and societal contexts for forest biotechnologies. In: Strauss, S.H. \& Bradshaw, H.D. (Eds.). The bioengineered forest. Resources of the future, Washington, USA, pp. 3-11.

Schuler T.H., Poppy G.M., Kerry B.R., Denholm I. (1998). Insect-resistant transgenic plants. Trends in Biotechnology 16: 168-175. http://dx.doi.org/10.1016/S0167-7799(97)01171-2

Schuler T.H., Denholm I., Jouanin L., Clark S.J., Clark A.J., Poppy G.M. (2001). Population-scale laboratory studies of the effect of transgenic plants on nontarget insects. Molecular Ecology 10: 1845-53. http://dx.doi.org/10.1046/j.0962-1083.2001.01309.x

Sedjo R.A. (2006). GMO Trees: Substantial promise but serious obstacles to commercialization. Silvae Genetica 55: 241-252.

http://germanjournalofforestresearch.com/fileadmin/content/dokument/archiv/silvaegen etica/55_2006/55-6-241.pdf

Sedjo R.A. (2010). Social, legal and regulatory issues related to transgenic trees. In ElKassaby, Y. (ed.): Forests and Genetically modified trees. FAO, Rome, 2010, pp. 203211.

www.fao.org/docrep/013/i1699e/i1699e.pdf

Semenov A.V., van Elsas J.D., Glandorf D.C.M., Schilthuizen M., de Boer W.F. (2013).

The use of statistical tools in field testing of putative effects of genetically modified plants on nontarget organisms. Ecology and Evolution 3: 2739-2750.

http://dx.doi.org/10.1002/ece3.640

Seppänen, E.J., 1970. Suomen suurperhostoukkien ravintokasvit. WSOY, Porvoo-Helsinki. 179 pp. (In Finnish)

Seppänen S.-K., Syrjälä L., von Weissenberg K., Teeri T.H., Paajanen L., Pappinen A. 
(2004). Antifungal activity of stilbenes in in vitro bioassays and in transgenic Populus expressing a gene encoding pinosylvin synthase. Plant Cell Reports 22: 584-593. http://dx.doi.org/10.1007/s00299-003-0728-0

Seppänen S.-K., Pasonen, H.-L-., Vauramo, S., Vahala, J., Toikka, M., Kilpeläinen, I., Setälä, H., Teeri, T.H., Timonen, S., Pappinen, A. (2007). Decomposition of the leaf litter and mycorrhiza forming ability of silver birch with a genetically modified lignin biosynthesis pathway. Applied Soil Ecology 36: 100-106. http://dx.doi.org/10.1016/j.apsoil.2006.12.002

Shakhbazau A.V., Kartel N.A. (2008). Chitinases in Bioengineering Research. Russian Journal of Genetics 44: 881-889. http://dx.doi.org/10.1134/S1022795408080012

Sharples F.E. (1983). Spread of organisms with novel genotypes: thoughts from an ecological perspective. Recombinant DNA Technical Bulletin16: 43-56.

Shin D.I., Podila G.K., Karnosky D.F. (1994). Transgenic larch expressing genes for herbicide and insect resistance. Canadian Journal of Forest Research 24: 2059-2067. http://dx.doi.org/10.1139/x94-264

Silfver T., Roininen H., Oksanen E., Rousi, M. (2009). Genetic and environmental determinants of silver birch growth and herbivore resistance. Forest Ecology and Management 257: 2145-2149. http://dx.doi.org/10.1016/j.foreco.2009.02.020

Silfver T., Rousi M., Oksanen E., Roininen H. (2014). Genetic and environmental determinants of insect herbivore community structure in a Betula pendula population. [v1; ref status: indexed, http://f1000r.es/2pd] F1000Research 3: 34. http://dx.doi.org/10.12688/f1000research.3-34.v1

Sinkkonen A., Somerkoski E., Paaso U., Holopainen J.K., Rousi M., Mikola J. (2012). Genotypic variation in yellow autumn leaf colours explains aphid load in silver birch. New Phytologist 195: 461-9. http://dx.doi.org/10.1111/j.1469-8137.2012.04156.x

Snow A.A., Andow D.A., Gepts P., Hallerman, E.M., Power A., Tiedje J.M. Wolfenbarger L.L. (2005). Genetically engineered organisms and the environment: Current status and recommendations. Ecological Applications 15: 377-404. http://dx.doi.org/10.1890/04-0539

Stefani F.O.P., Hamelin R.C. (2010). Current state of genetically modified plant impact on target and non-target fungi. Environmental Reviews 18: 441-475. http://dx.doi.org/10.1139/A10-022

Strauss S.H., Brunner A.M., Busov V.B., Ma C., Meilan R. (2004). Ten lessons from 15 years of transgenic Populus research. Forestry 77: 455-465. http://dx.doi.org/10.1093/forestry/77.5.455

Strauss S.H.,Tan H., Boerjan' W., Sedjo R. (2009). Strangled at birth? Forest biotech and the Convention on Biological Diversity. Nature Biotechnology 27: 519-527. http://dx.doi.org/10.1038/nbt0609-519

Stout M.J., Thaler J.S., Thomma B.P.H.J. (2006). Plant-mediated interactions between pathogenic microorganisms and herbivorous arthropods. Annual Review of Entomology 51: 663-689. http://dx.doi.org/10.1146/annurev.ento.51.110104.151117

Sun C.X., Qi H., Hao J.J., Miao L.,Wang J.,Wang Y., Liu M., Chen L.J. (2009). Single leaves photosynthetic characteristics of two insect-resistant transgenic cotton (Gossypium hirsutum L.) varieties in response to light. Photosynthetica 47: 399-408. 
http://dx.doi.org/10.1007/s11099-009-0061-0

Sun C.X., Yuan F., Zhang Y.L., Cui Z.B., Chen Z.H., Chen L.J. Wu Z.J. (2013).

Unintended effects of genetic transformation on photosynthetic gas exchange, leaf reflectance and plant growth properties in barley (Hordeum vulgare L.) Photosynthetica 51: 22-32.

http://dx.doi.org/10.1007/s11099-013-0002-9

Tahvanainen J., Julkunen-Tiitto R., Rousi M., Reichardt P.B. (1991). Chemical determinants of resistance in winter-dormant seedlings of European white birch (Betula pendula) to browsing by the mountain hare. Chemoecology 2: 49-54.

http://dx.doi.org/10.1007/BF01240666

Tang W., Tian Y. (2003). Transgenic loblolly pine (Pinus taeda L.) plants expressing a modifed d-endotoxin gene of Bacillus thuringiensis with enhanced resistance to Dendrolimus punctatus Walker and Crypyothelea formosicola Staud. Journal of Experimental Botany 54: 835-844.

http://dx.doi.org/10.1093/jxb/erg071

Tellam R.L., Eisemann C. (2000). Chitin is only a minor component of the peritrophic matrix from larvae of Lucilia cuprina. Insect Biochemistry and Molecular Biology 30: 1189-1201. http://dx.doi.org/10.1016/S0965-1748(00)00097-7

Tiimonen H., Aronen T., Laakso T., Saranpää P., Chiang V., Ylioja T., Roininen H., Häggman H. (2005). Does lignin modification affect feeding preference or growth performance of insect herbivores in transgenic silver birch (Betula pendula Roth). Planta 222: 699-708. http://dx.doi.org/10.1007/s00425-005-0002-5

Tikkanen O.-P., Lyytikäinen-Saarenmaa P. (2002). Adaptation of a generalist moth, Operophtera brumata, to variable budburst phenology of host plants. Entomologia Experimentalis et Applicata 103: 123-133. http://dx.doi.org/10.1023/A:1020305006274

Tzfira T., Zucker A., Altman A. (1998). Forest-tree biotechnology: genetic transformation and its application to future forests. Trends in Biotechnology 16: 439-446. http://dx.doi.org/10.1016/S0167-7799(98)01223-2

Valenzuela S., Balocchi C., Rodríguez J. (2006). Transgenic trees and forestry biosafety. Electronic Journal of Biotechnology 9(3): 335-339. http://dx.doi.org/10.2225/vo19-issue3-fulltext-22

Vauramo S., Pasonen H.-L., Pappinen A., Setälä H. (2006). Decomposition of leaf litter from chitinase transgenic silver birch (Betula pendula) and effects on decomposer populations in a field trial. Applied Soil Ecology 32: 338-349.

http://dx.doi.org/j.apsoil.2005.07.007

Vellice, G.R., Diaz Ricci, J.C., Hernández, L. \& Castagnaro, A.P. (2006). Enhanced resistance to Botrytis cinerea mediated by the transgenic expression of the chitinase gene ch5B in strawberry. Transgenic Research 15: 57-68. http://dx.doi.org/10.1007/s11248-005-2543-6

Veluthakkal R., Karpaga Raja Sundari B., Ghosh Dasgupta M. (2012). Tree chitinases stress- and developmental-driven gene regulation. Forest pathology 42: 271-278. http://dx.doi.org/10.1111/j.1439-0329.2011.00759.x

Walling L.L. (2000). The Myriad Plant Responses to Herbivores. Journal of Plant Growth Regulation 19: 195-216. http://dx.doi.org/10.1007/s003440000026 
Walter C., Fladung M., Boerjan W. (2010). The 20-year environmental safety record of GM trees. Nature Biotechnology 28: 656-658. http://dx.doi.org/10.1038/nbt0710-656

Wang J., Chen Z., Du J., Sun Y., Liang A. (2005). Novel insect resistance in Brassica napus developed by transformation of chitinase and scorpion toxin genes. Plant Cell Reports 24: 549-555. http://dx.doi.org/10.1007/s00299-005-0967-3

Wang Z., Xue Z., Fan H., Zhan Y. (2007). Resistance of transgenic Betula platyphylla to the defoliator Lymantria dispar. Scientia Silvae Sinicae 43: 116-120.

Wei H., Meilan R., Brunner A.M., Skinner J.S., Ma C., Gandhi H.T., Strauss S.H. (2006). Field trial detects incomplete barstar attenuationof vegetative cytotoxicity in Populus trees containing a poplar LEAFY promoter::barnase sterility transgene. Molecular Breeding 19: 69-85. http://dx.doi.org/10.1007/s11032-006-9045-y

von Weissenberg K. (1990). Host-parasite relationships in forest ecosystems: a review. Silva Fennica 24: 129-139. (In Swedish with English abstract)

Wilson A.K., Latham J.R., Steinbrecher R.A. (2006). Transformation-induced mutations in transgenic plants: Analysis and biosafety implications. Biotechnology and Genetic Engineering Reviews 23: 209-234. http://dx.doi.org/10.1080/02648725.2006.10648085

Winder R.S., Lamarche J., Constabel C.P., Hamelin R.C. (2013). The effects of high-tannin leaf litter from transgenic poplars on microbial communities in microcosm soils. Frontiers in Microbiology 4: 290. http://dx.doi.org/10.3389/fmicb.2013.00290

Wu K.-M., Lu Y.-H., Feng H.-Q., Jiang Y.-Y., Zhao J.-Z. (2008). Suppression of cotton bollworm in multiple crops in China in areas with Bt toxin-containing cotton. Science 321: 1676-1678. http://dx.doi.org/10.1126/science. 1160550

Yabor L., Valle B., Carvajal C., Aragón C., Hernández M., González J., Daquinta M., Arencibia A., Lorenzo J.C. (2010). Characterization of a field-grown transgenic pineapple clone containing the genes chitinase, AP24, and bar. In Vitro Cellular \& Developmental Biology - Plant 46: 1-7. http://dx.doi.org/10.1007/s11627-009-9245-3

Yang L.Y. (2008). Bioassays of resistance of transgenic poplar with novel binary insectresistant genes to Anoplophora glabripennis (Coleoptera: Cerambycidae) and Hyphantria cunea (Lepidoptera: Arctiidae). Acta Entomologica Sinica 51: 844-848.

Yang M.S., Lang H.Y., Gao B.J., Wang J.M., Zheng J.B. (2003). Insecticidal activity and transgene expression stability of transgenic hybrid poplar clone 741 carrying two insect-resistant genes. Silvae Genetica 52: 197-201.

Yang L.Y., Sun Y., Hao Y.S. \&Wang Y.X. (2013). Effects of transgenic poplar leaves with binary insect-resistance genes used as feed for rabbits. World Rabbit Science 21: 257261.

http://dx.doi.org/10.4995/wrs.2013.1188

Ylioja T., Saranpää P., Roininen H., Rousi M. (1998). Larval tunnels of Phytobia betulae (Diptera: Agromyzidae) in birch wood. Journal of Economic Entomology 91: 175-181. http://dx.doi.org/10.1093/jee/91.1.175

Ylioja T., Roininen H., Ayres M.P., Rousi M., Price P.W. (1999). Host-driven population dynamics in an herbivorous insect. PNAS 96: 10735-10740. 
http://dx.doi.org/10.1073/pnas.96.19.10735

Zhang B., Chen M., Zhang X., Luan H., Tian Y., Su X. (2011). Expression of Bt-Cry3A in transgenic Populus alba x P. glandulosa and its effects on target and non-target pests and the arthropod community. Transgenic Research 20: 523-532. http://dx.doi.org/10.1007/s11248-010-9434-1

Zhang Z., Wang J., Zhang J., Zhang S. (2004). Effects of transgenic poplars to the structure of insect community. Scientia Silvae Sinicae 40: 84-89. (in Chinese with English abstract)

Zvereva E.L., Lanta V., Kozlov M.E. (2010). Effects of sap-feeding insect herbivores on growth and reproduction of woody plants: a meta-analysis of experimental studies. Oecologia 163: 949-960.

http://dx.doi.org/10.1007/s00442-010-1633-1 